\title{
MEN1 silencing aggravates tumorigenic potential of AR-independent prostate cancer cells through nuclear translocation and activation of JunD and $\beta$-catenin
}

Yakun Luo ${ }^{1}$, Virginie Vlaeminck-Guillem ${ }^{1,2}$, Silvère Baron ${ }^{3}$, Sarah Dallel ${ }^{3}$, Chang Xian Zhang ${ }^{1 *}$ and Muriel Le Romancer'

\begin{abstract}
Background: Recent studies highlighted the increased frequency of AR-low or -negative prostate cancers (PCas) and the importance of AR-independent mechanisms in driving metastatic castration-resistant PCa (mCRPC) development and progression. Several previous studies have highlighted the involvement of the MEN1 gene in PCa. In the current study, we focused on its role specifically in AR-independent PCa cells.

Methods: Cell tumorigenic features were evaluated by proliferation assay, foci formation, colony formation in soft agar, wound healing assay and xenograft experiments in mice. Quantitative RT-PCR, Western blot and immunostaining were performed to determine the expression of different factors in human PCa lines. Different ChIP-qPCR-based assays were carried out to dissect the action of JunD and $\beta$-catenin.

Results: We found that MEN1 silencing in AR-independent cell lines, DU145 and PC3, resulted in an increase in anchorage independence and cell migration, accompanied by sustained MYC expression. By searching for factors known to positively regulate MYC expression and play a relevant role in PCa development and progression, we uncovered that MEN1-KD triggered the nuclear translocation of JunD and $\beta$-catenin. ChIP and $3 C$ analyses further demonstrated that MEN1-KD led to, on the one hand, augmented binding of JunD to the MYC $5^{\prime}$ enhancer and increased formation of loop structure, and on the other hand, increased binding of $\beta$-catenin to the MYC promoter. Moreover, the expression of several molecular markers of EMT, including E-cadherin, BMI1, Twist1 and HIF-1a, was altered in MEN1-KD DU145 and PC3 cells. In addition, analyses using cultured cells and PC3-GFP xenografts in mice demonstrated that JunD and $\beta$-catenin are necessary for the altered tumorigenic potential triggered by MEN1 inactivation in AR-independent PCa cells. Finally, we observed a significant negative clinical correlation between MEN1 and CTNNB1 mRNA expression in primary PCa and mCRPC datasets.
\end{abstract}

Conclusions: Our current work highlights an unrecognized oncosuppressive role for menin specifically in ARindependent PCa cells, through the activation of JunD and $\beta$-catenin pathways.

Keywords: Prostate cancer, AR-independent cells, MEN1, JunD, $\beta$-Catenin

\footnotetext{
* Correspondence: chang.zhang@lyon.unicancer.fr

'Université Lyon, Université Claude Bernard Lyon 1, INSERM 1052, CNRS 5286

Centre Léon Bérard, Centre de recherche en cancérologie de Lyon, 69008 Lyon, France

Full list of author information is available at the end of the article
}

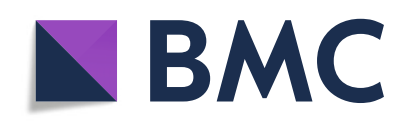

(- The Author(s). 2021 Open Access This article is licensed under a Creative Commons Attribution 4.0 International License, which permits use, sharing, adaptation, distribution and reproduction in any medium or format, as long as you give appropriate credit to the original author(s) and the source, provide a link to the Creative Commons licence, and indicate if changes were made. The images or other third party material in this article are included in the article's Creative Commons licence, unless indicated otherwise in a credit line to the material. If material is not included in the article's Creative Commons licence and your intended use is not permitted by statutory regulation or exceeds the permitted use, you will need to obtain permission directly from the copyright holder. To view a copy of this licence, visit http://creativecommons.org/licenses/by/4.0/. The Creative Commons Public Domain Dedication waiver (http://creativecommons.org/publicdomain/zero/1.0/) applies to the data made available in this article, unless otherwise stated in a credit line to the data. 


\section{Background}

With over 1.4 million new cases and more than 370,000 deaths reported worldwide in 2020 [1], prostate cancer (PCa) remains a major cause of cancer-related mortality and morbidity in men worldwide. The majority of PCas express the androgen receptor (AR), and dysregulation of the androgen pathway is key to the development and progression of $\mathrm{PCa}$ [2]. Androgen deprivation therapies (ADT) are, therefore, a highly effective frontline treatment for PCa [3]. However, ADT are characterized by the virtually unavoidable emergence of resistance, termed castration-resistant PCas (CRPCs), often metastatic (mCRPC) and with a high mortality rate $[1,4]$. Genomic characterization of CRPCs has led to their subdivision into two subtypes: (1) AR-dependent CRPCs, containing alterations in the AR gene, such as amplification, point mutations, and generation of splice variants; and (2) AR-independent CRPCs, in which resistant cells lack AR expression or signaling [5]. Markedly, among these AR-independent CRPCs, some PCas express neither the AR nor markers of neuroendocrine (NE) differentiation ("AR null-NE null", or double negative $\mathrm{PCa}$, DNPC), and their incidence has risen over the past 2 decades from 5\% in 1998-2011 to 23\% in 2012-2016 [6]. Owing to the heterogeneous nature of the disease, addressing the mechanisms specifically underlying different subtypes of $\mathrm{PCa}$ is thus highly relevant.

Studies on DNPC and AR-independent mCRPC have considerably advanced our knowledge in this field over the last decade. By extensively characterizing cellular markers of the related lesions and cell models, cell dedifferentiation and/or altered cell plasticity were proposed to be critical for the development and evolution of these cancers [7]. Among these alterations, epithelial-tomesenchymal transition (EMT), often in conjunction with stem cell-like changes, is considered to be crucial in the development of AR-negative PCas. The protooncogene MYC, a potent transcription factor that controls various biological processes [8-12], was reported to be one of the key drivers of CRPC and neuroendocrine prostate cancer (NEPC) [13-15]. Furthermore, several genetic factors and signaling pathways were shown to bypass AR pathways and thus be involved in ARindependent PCa development, such as P53 [16], RB1 [16], PTEN [17], glucocorticoid receptor (GR) [18], FGF [6] and Stat3/5, as well as the metabolic ACSL pathway $[19,20]$, whereas the underlying mechanisms remain elusive.

We have previously observed that male heterozygous Men1 mutant mice developed PCa with a low but significant frequency [21]. However, Malik et al. reported that the physical interaction between menin and AR was essential for the growth of human PCa cell lines both in culture and in xenografts [22]. Recently, we demonstrated the decisive role played by the menin protein, encoded by the MEN1 gene, in regulating $A R$ transcription in ARdependent $\mathrm{PCa}$ cell lines [23]. Our findings also highlighted disparities in the effects of this protein on the proliferation of PCa cells, since MEN1 silencing had no impact (PC3 cells), or even an increased (DU145 cells) proliferation of AR-independent cells, whereas it led to a marked decrease in cell growth of AR-dependent lines (LNCaP, 22Rv1 and VCaP). The distinct role of the MEN1 gene in these two $\mathrm{PCa}$ cell populations, albeit intriguing, is not surprising, considering the different cellular and molecular mechanisms involved in their tumorigenesis. Indeed, the MEN1 gene is largely known as a tumor suppressor in several types of endocrine tissues, since its mutation predisposes patients to multiple endocrine neoplasia type 1 syndrome (MEN1 syndrome, OMIM 131100). However, it is now well established that menin displays oncogenic effects in certain types of leukemia containing fusion MLL caused by chromosome translocation [24]. Dreijerink et al. found that the gene expression profile obtained after MEN1 silencing in normal mammary luminal progenitors was highly distinct from that found in ER-positive breast cancer MCF7 cells, suggesting that menin regulates different gene sets in normal mammary luminal cells versus ER-positive breast cancer cells [25]. Here, we focused on the mechanisms underlying the distinct effects observed upon MEN1 silencing in ARindependent PCa cells. Through different analyses using cultured cells and in vivo experiments, our data unveiled the activation of the JunD and $\beta$-catenin pathways upon menin inactivation in AR-independent PCa cells, underscoring menin as an oncosuppressive factor in these cells, in marked contrast to its role in AR-dependent PCa cells.

\section{Materials and methods}

\section{Cell culture and treatment}

Prostate cancer cell lines were purchased from ATCC. Their authentication was renewed recently and $\mathrm{Myco}$ plasma testing was carried out regularly. LNCaP, 22Rv1 and DU145 were cultured in RPMI medium, and PC3 cells in F-12 medium (Gibco Invitrogen), at $37^{\circ} \mathrm{C}$ with $5 \% \mathrm{CO}_{2}$. Inhibition of menin-MLL interaction was achieved through the use of MI503 (Active Biochem).

\section{Cell proliferation and foci formation assays}

Cell proliferation assays were performed as described previously [23]. For foci formation assays, cells were seeded in 6-well culture plates at $5 \times 10^{2}$ cells for LNCaP, and at $2.5 \times 10^{2}$ cells for $22 \mathrm{Rv} 1$, DU145 or PC3. Cells were transfected with siRNA or treated with MI503, and cultured for 2 weeks. The ensuing colonies were stained with $0.05 \%$ crystal violet. The images of the plates were analyzed using Image J software. Each 

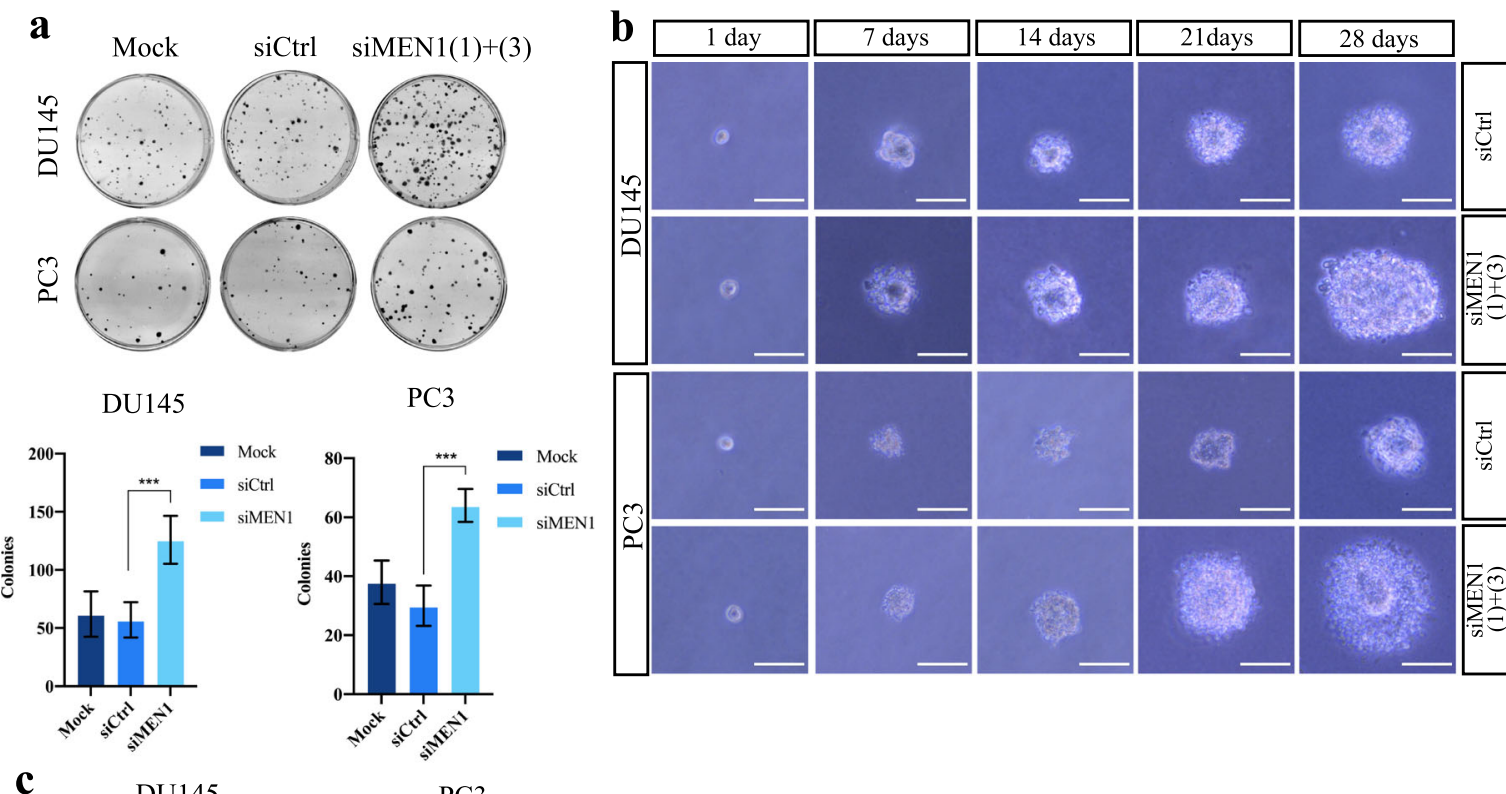

PC3
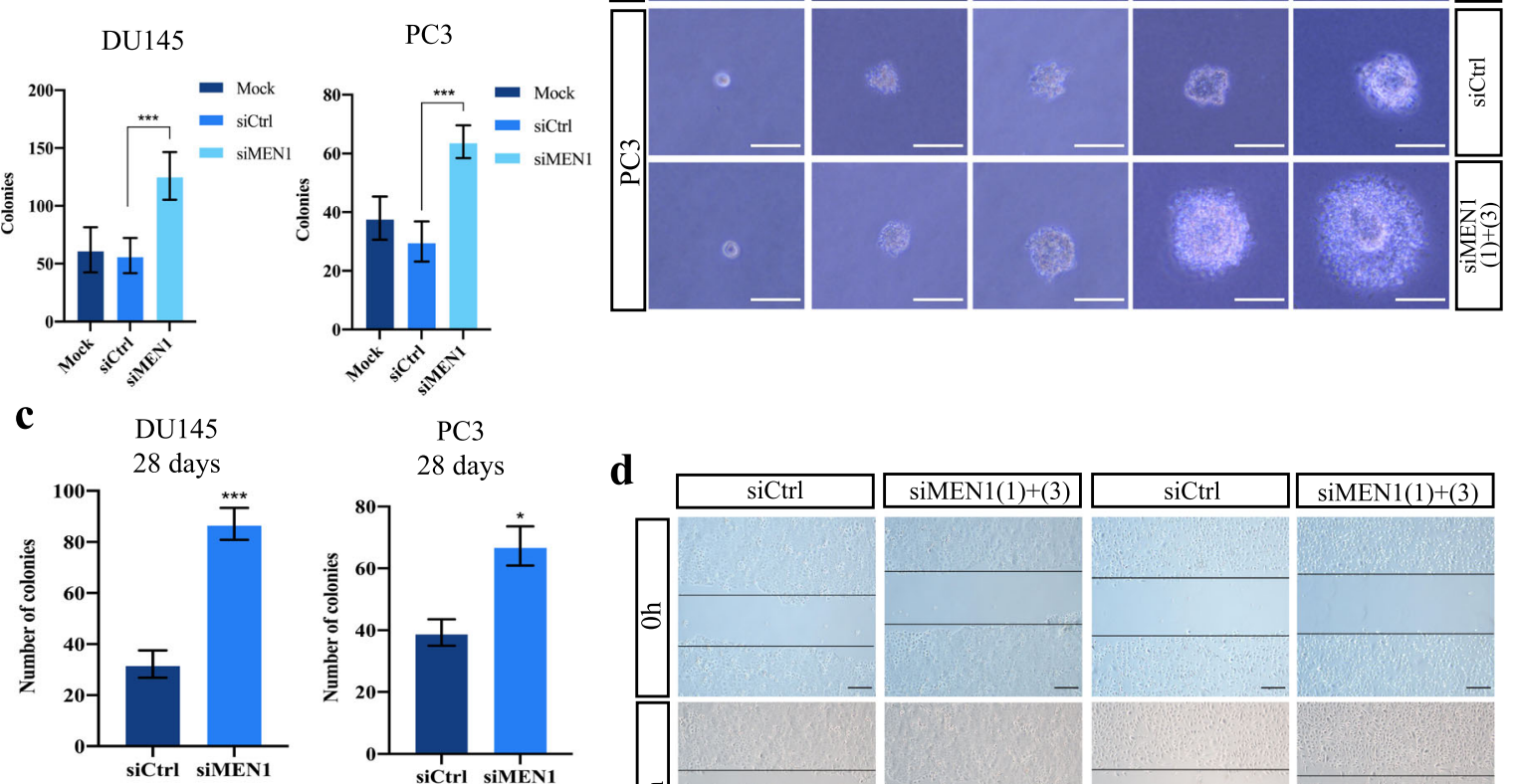

e
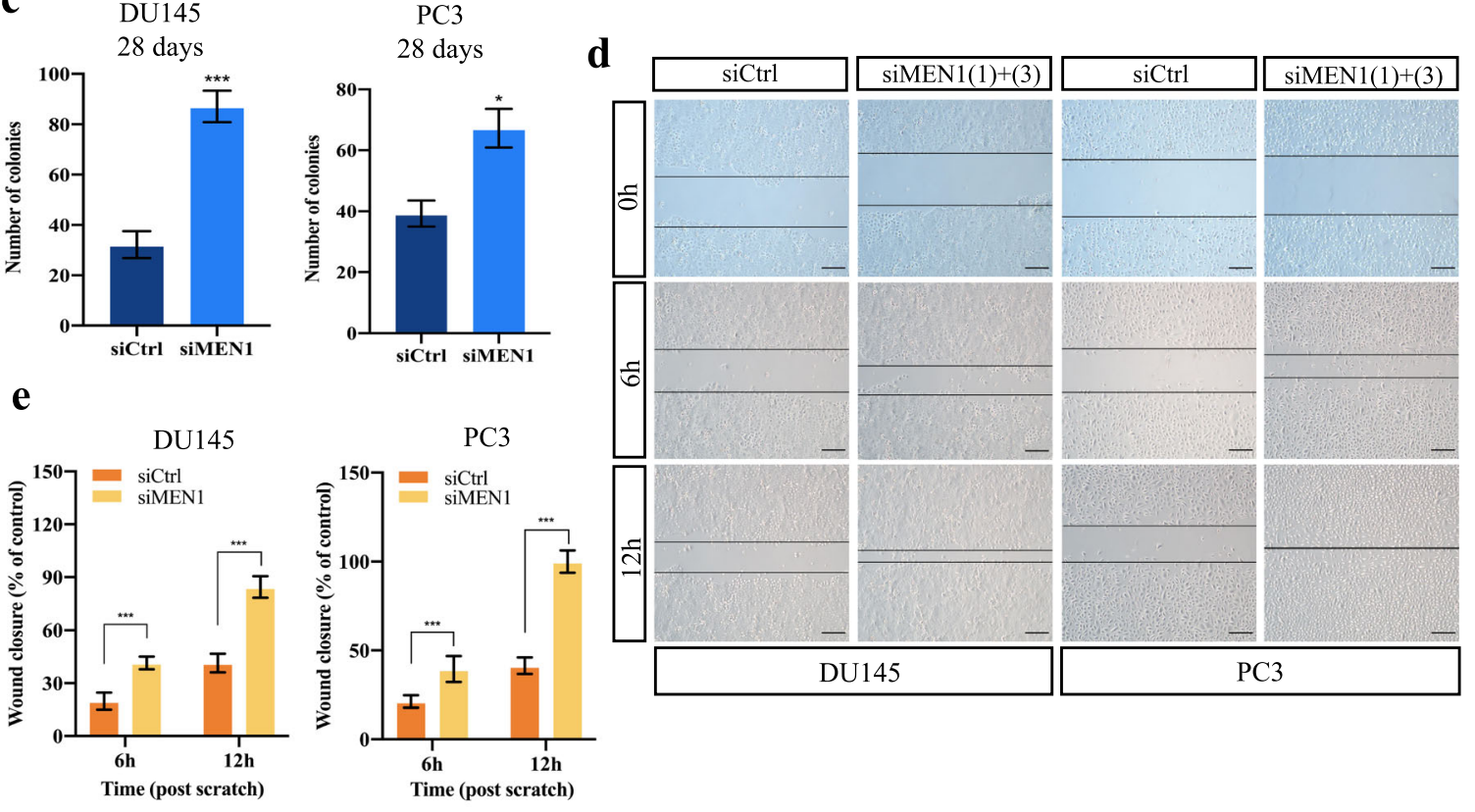

f

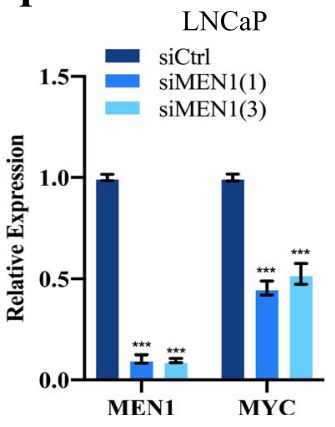

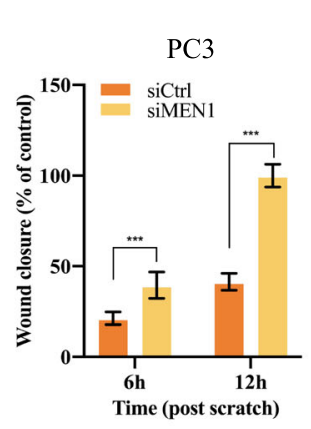
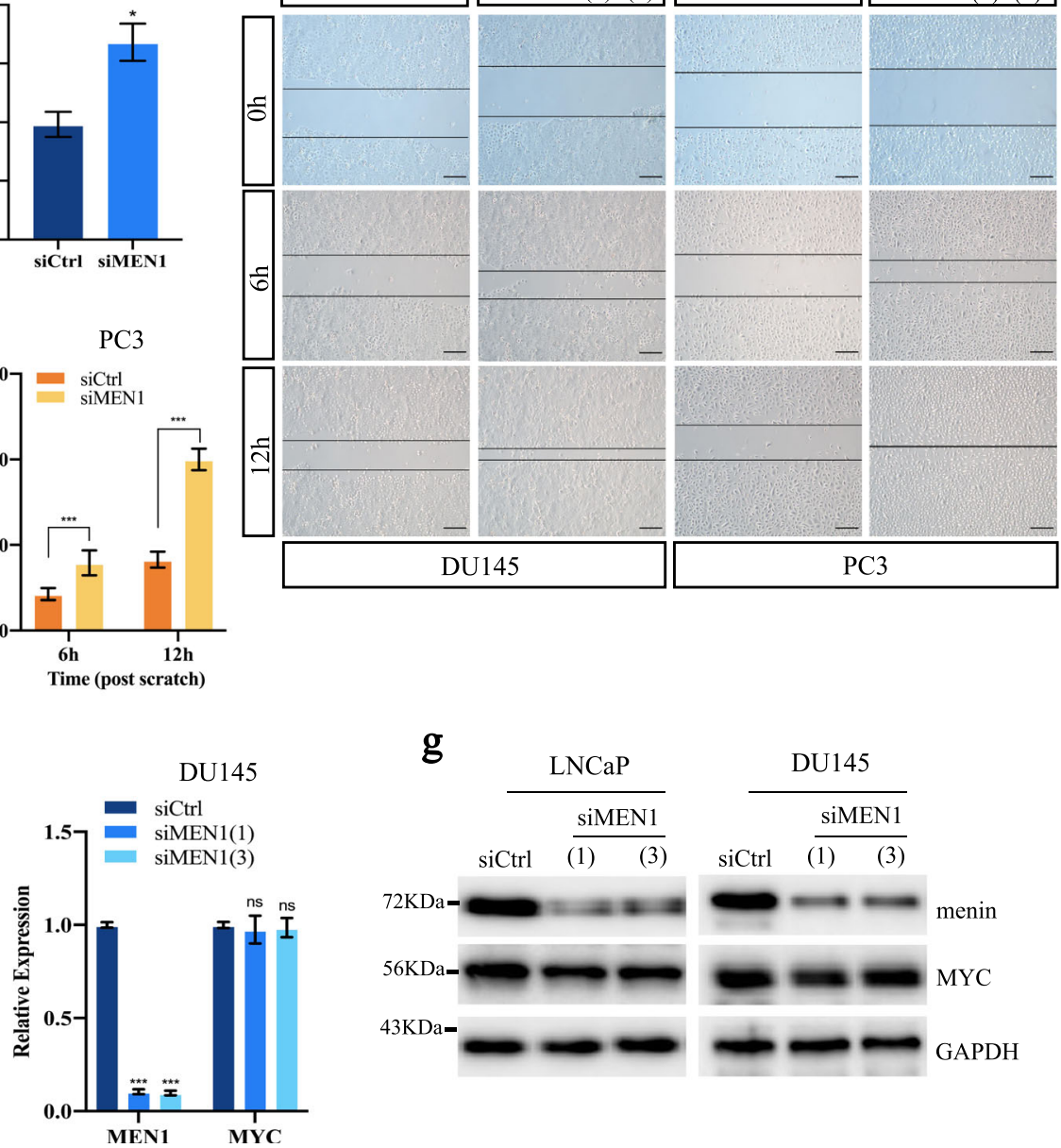

g
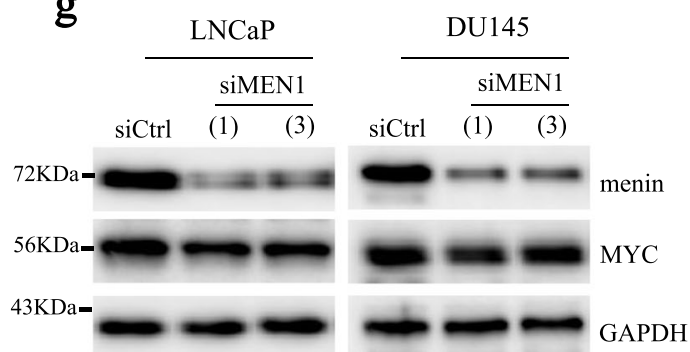

Fig. 1 (See legend on next page.) 
(See figure on previous page.)

Fig. 1 MEN1 silencing promotes anchorage independence and cell migration in AR-independent PCa cells with maintained MYC expression. a Upper panel: Representative images of foci formation assay with DU145 and PC3 cells treated with siMEN1(1) + (3) or siCrtl. Lower panel: Quantification of foci formation assay. b Representative images of soft agar colony formation assay in MEN1-KD DU145 or PC3 cells. Scale bar= 50 um. c Bar charts showing colony formation 28 days post-transfection with siMEN1 or siCtrl, extrapolated from images using Image J software. d Representative images of scratch wound healing assays using siMEN1 or siCtrl-transfected DU145 and PC3 cells. Scale bar $=200 \mu \mathrm{m}$. e Graphs indicating cell migration displayed in terms of the $\%$ wound closure $6 \mathrm{~h}$ and $12 \mathrm{~h}$ post-wounding $(\mathrm{t}=0$, as control). $\mathbf{f}$ and $\mathbf{g}$ Quantitative RT-PCR (qRT-PCR) analysis of MYC transcripts (f) and Western blot analysis of MYC protein levels (g) in PCa cells treated with siCtrl or siMEN1(1) + (3) for $72 \mathrm{~h}$. Representative blots were as performed of three independent experiments

experiment was conducted in triplicate and statistical analyses were performed using the Prism software.

\section{Scratch wound healing assay}

Cell migration capacities were evaluated through wound healing assays. $5 \times 10^{3}$ cells were seeded onto 6-well plates. After $24 \mathrm{~h}$ in culture, cells were transfected with $20 \mathrm{nM}$ of siRNA. $72 \mathrm{~h}$ after transfection, wounds were created, and wound closures were captured at 0,6 , and $12 \mathrm{~h}$.

\section{Colony formation in soft agar}

Soft agar assays were performed as described previously [26]. After 4 weeks of incubation at $37^{\circ} \mathrm{C}$, colonies were stained with $0.05 \%(\mathrm{w} / \mathrm{v})$ crystal violet (Sigma) and colonies were counted using Image J software.

\section{Xenograft tumor growth test}

Xenografts were performed using 8-week-old male NOD-Scidy mice by surgical implantation under the kidney capsule. $1 \times 10^{5}$ PC3-GFP cells were encapsulated in a collagen matrix as previously described [27]. Five days after implantation, mice were randomized into two groups and treated three-times a week for 1 month. Mouse groups were treated with i.p. injections of menin inhibitor MI503 $75 \mathrm{mg} / \mathrm{kg}$ (MedChemTronica) $(n=11)$ or Vehicle solution (DMSO/PEG300, Sigma-Aldrich) $(n=9)$. One month after, xenografted tissues were collected after necropsy and processed for further analyses. The quantification of the number of PC3-GFP cells in xenografted tissues by qPCR assay was performed as previously described [28]. All experiments were approved by Auvergne Ethics Committee (CEMEAA) and registered according the approval number 172962018102216428025 v3.

\section{RNA interference and transfection}

Transfection of siRNA was performed using Lipofectamine 2000 (Invitrogen) according to the manufacturer's instructions, and incubated for $72 \mathrm{~h}$.

RNA extraction, reverse transcription, and real-time PCR Total RNA from cultured cells was extracted using the RNeasy-Kits (Qiagen, Valencia, USA) as per manufacturer's instructions. cDNAs were amplified and quantified in an ABI Prism 7500 Sequence Detection System (Applied Biosystems) using the SYBR Green I dye (SsoAdvanced Universal SYBR Green, Bio-Rad). Data were normalized against the in-house control HPRT and represented as fold change. Primers used are listed in the Supplementary information.

\section{Protein extraction and Western blotting}

Subcellular fractions were separated using NE-PER Nuclear and Cytoplasmic Extraction Reagents (ref. 78,833 , Thermo Scientific). Western blotting was carried out according to the method described previously [29].

\section{Immunofluorescence (IF) and immunohistochemistry (IHC) staining}

For IF staining, cells were grown on glass coverslips, then fixed with methanol for $5 \mathrm{~min}$ at room temperature. Following fixation, cells were blocked with Dako buffer (S0809, Agilent) for $1 \mathrm{~h}$, and incubated with primary antibodies overnight at $4{ }^{\circ} \mathrm{C}$, then with appropriate secondary antibodies conjugated with Alexa 555 (red) or Alexa 488 (green) (Cell Signaling Technology). Cells were counterstained with DAPI (DUO82040, SigmaAldrich) for $10 \mathrm{~min}$ and visualized by fluorescence microscopy (Eclipse-NiE NIKON microscope).

Xenografts were collected and fixed in 4\% PFA prior to paraffin embedding, sectioning, staining with hematoxylin and eosin, and with immunostaining conducted as described previously [23]. Images were acquired on a ZEISS Axioscope 5 microscope.

\section{Chromatin immunoprecipitation (ChIP) and sequential ChIP (reChIP) assays}

Chromatin immunoprecipitation (ChIP) was performed with the Millipore ChIP Assay Kit (17-295) as described previously [23]. Briefly, cells were crosslinked with $1 \%$ formaldehyde for $10 \mathrm{~min}$ at $37^{\circ} \mathrm{C}$. Chromatin was prepared according to the Millipore protocol and sonicated to an average size of $300-500 \mathrm{bp}$ using a Diagenode Bioruptor. Chromatin fragments were immunoprecipitated at $4{ }^{\circ} \mathrm{C}$ overnight with menin antibody or normal rabbit IgG used as a negative control (see references of antibodies in the Supplementary information ), and 

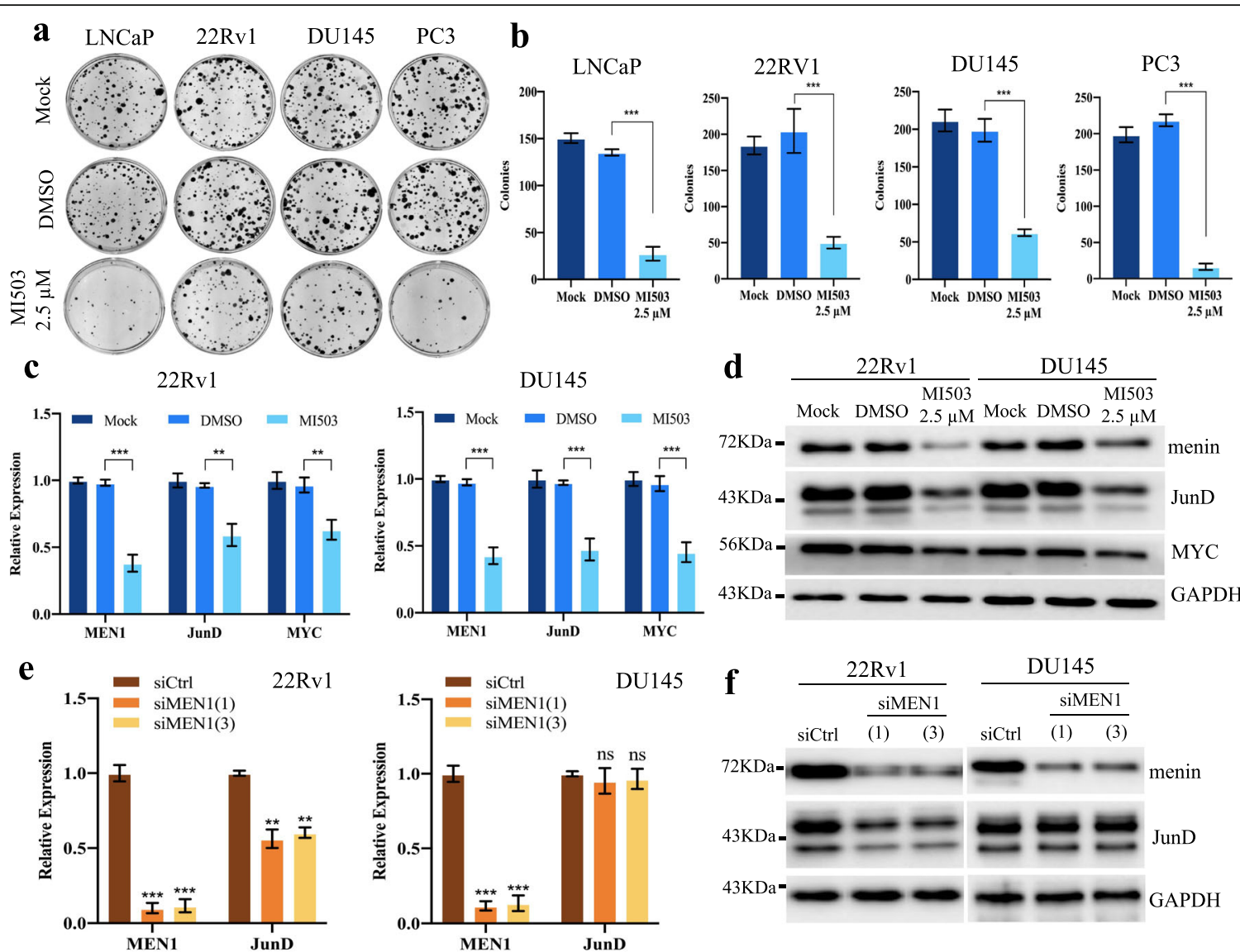

Mock DMSO MI503 MI503
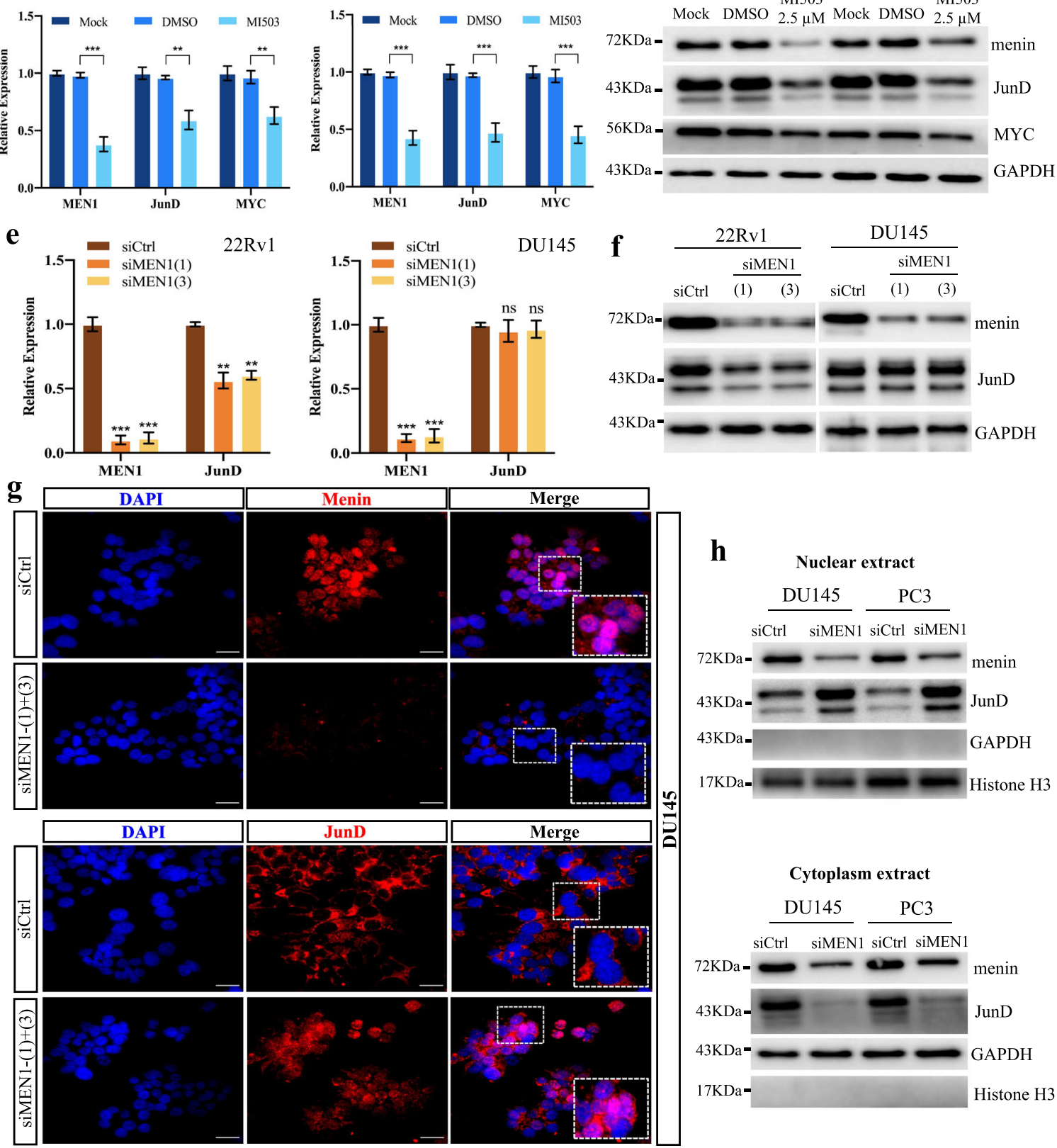

h

Nuclear extract
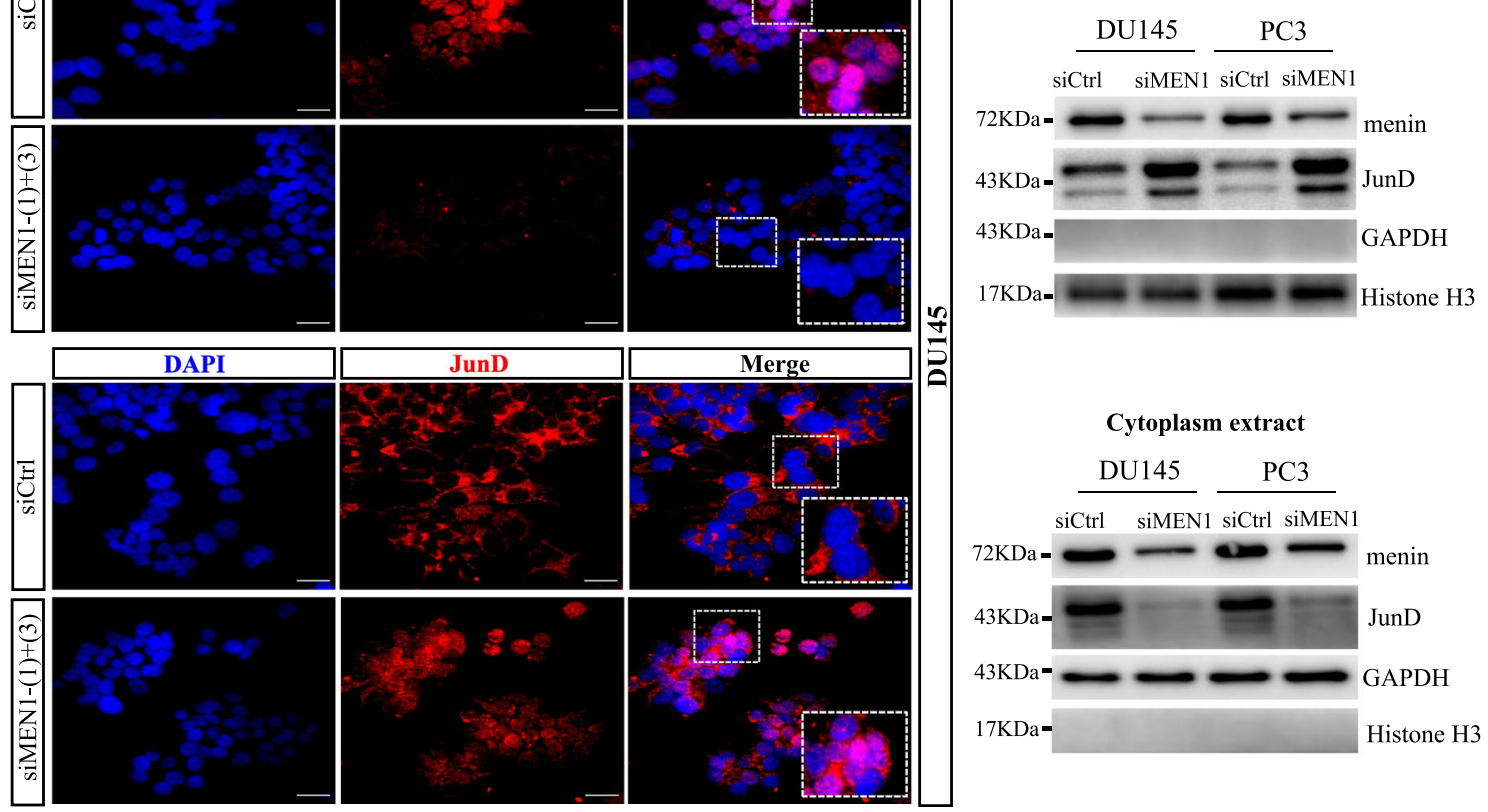

Fig. 2 (See legend on next page.) 
(See figure on previous page.)

Fig. 2 MEN1 silencing triggers the nuclear translocation of JunD in AR-independent PCa cells. Representative images of foci formation assays (a) and their quantification (b) using LNCaP, 22Rv1, DU145 and PC3 cells treated or not with MI503 (2.5 $\mu \mathrm{M})$. qRT-PCR analysis of JunD and MYC mRNA expression (c) and Western blot analysis showing JunD and MYC expression (d) in 22Rv1 and DU145 cells treated or not with MI503 $(2.5 \mu \mathrm{M})$. qRT-PCR analysis of JunD mRNA expression (e) and Western blot analysis of JunD protein expression (f) in MEN1-KD 22 Rv1 and DU145 cells. $\mathbf{g}$ IF staining showing menin and JunD in DU145 cells treated with siCtrl or siMEN1(1) + (3). Scale bar $=25 \mu \mathrm{m}$. $\mathbf{h}$ Western blot analysis of JunD expression in different subcellular fractions in DU145 and PC3 cells treated with siCtrl or siMEN1(1) + (3). Representative blots of three independent experiments

immune complexes were collected on Protein A agarose beads (ChIP assay kit, 17-295, Millipore).

For reChIP assays, the first immunoprecipitated chromatin complexes were washed and eluted with $10 \mathrm{mM}$ dithiothreitol at $37^{\circ} \mathrm{C}$ for $30 \mathrm{~min}$ and diluted 50-fold with ChIP dilution buffer. The second immunoprecipitations were then performed [30]. Each ChIP or reChIP assay was repeated at least three times independently. Primers used for ChIP-qPCR are listed in the Supplementary information.

\section{Chromosome conformation capture (3C) assay and ChIP-3C} $3 \mathrm{C}$ and ChIP-3C assays were performed as described previously [31-33]. A comprehensive description of all the process of experiment, reagents, kits, antibodies, and primers used in this study can be found in Supplementary information.

\section{Raw data for mining analysis}

The cBioPortal for cancer genomics (http://www. cbioportal.org) [34] was employed to analyze mRNA coexpression between MEN1 and JUnD, MEN1 and CTNNB1 in PCa. Data on the correlation between $M E N 1$ and $J u n D$ mRNA expression were download from SU2C/PCF Dream team (mCRPC) [35] and Firehose Legacy team and PanCancer Altas team (Primary prostate adenocarcinoma) [36].

\section{Statistical analysis}

All experiments were repeated at least three times to ensure accuracy. The values are expressed as mean \pm standard deviation (S.D.) and analyzed by Student $t$ test. The level of significance: ns, non-significant vs Ctrl, ${ }^{*} P<0.05$, ** $P<0.01$, *** $P<0.001$, for all analyses.

\section{Results}

MEN1 silencing promotes the tumorigenic potential and maintains MYC expression in AR-independent PCa cells

Our previous results, showing that MEN1 silencing had distinct effects on cell proliferation of AR-dependent versus AR-independent $\mathrm{PCa}$ cells [23], prompted us to dissect cellular consequences of MEN1 inactivation in AR-independent PCa cells. Firstly, we performed foci formation and soft agar assays to assess cell tumorigenic potential in MEN1-knockdown (KD) PCa cells. MEN1-
KD resulted in a significant increase in colony formation in AR-independent PCa cells (DU145 and PC3) in both tests (Fig. 1a-b), whereas it had the opposite effect in AR-dependent PCa cells (LNCaP and 22Rv1) tested for foci formation (Fig. S1a-b). Interestingly, MEN1-KD also led to a decreased number of colonies formed in PC3 cells re-expressing AR (PC3-AR), to a lesser extent than in AR-dependent cells but significantly greater than ARindependent PCa cells (Fig. S1a-b), consistent with the previously observed reduced cell proliferation in MEN1KD PC3-AR cells [23]. The efficiency of MEN1 silencing was confirmed by Western blotting (Fig. S1b). In soft agar assays, MEN1-KD DU145 and PC3 cells gave rise not only to more foci, but also to larger ones, with colonies appearing more irregular in shape, compared with siCtrl-treated cells (Fig. 1b). Furthermore, to determine whether menin influenced cell migration, MEN1-KD DU145 and PC3 cells were subjected to scratch woundhealing assays, with wound closure being monitored at $6 \mathrm{~h}$ and $12 \mathrm{~h}$. A significant increasing in DU145 and PC3 cell migration was observed at these time-points following MEN1 silencing with siMEN1(1) + (3) (Fig. 1c-d), whereas this reduced cell migration of 22Rv1 and PC3AR cells (Fig. S1c). Taken together, MEN1-KD in DU145 and PC3 cells promoted cell growth in an anchorage-independent manner and increased cell migration, suggesting that menin plays a tumor suppressive role in AR-independent PCa cell lines, unlike its oncogenic role in AR-dependent PCa cell lines.

Intriguingly, $\mathrm{Wu}$ et al. demonstrated that menin physically interacts with MYC to enhance the transcription of MYC target genes in liver cancer cells [37]. We observed that, while MEN1-KD reduced the expression of MYC at the transcriptional and protein levels in LNCaP and 22Rv1 cells, its expression was maintained in the two MEN1-KD AR-independent PCa cells (Fig. 1f-g and Fig. S1d), suggesting that the difference in cellular activity between AR-dependent and AR-independent PCa cells could be, at least partially, due to MYC expression. Having shown that MEN1-KD increased the tumorigenic potential of ARindependent $\mathrm{PCa}$ cells and that MYC expression was maintained, we wondered whether factors known to regulate MYC expression could contribute to the effects triggered by MEN1 silencing. 


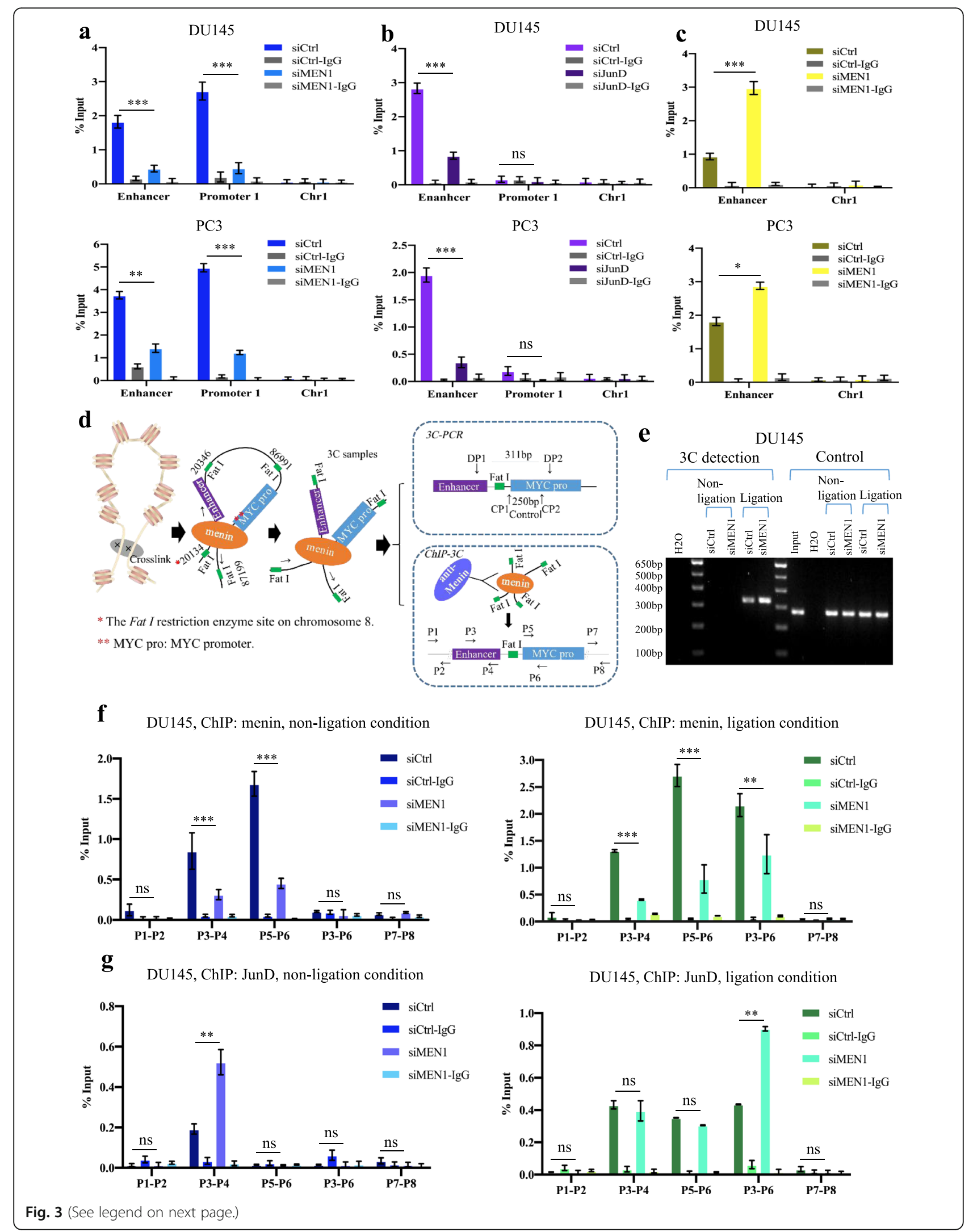


(See figure on previous page.)

Fig. 3 MEN1 knockdown leads to increased JunD binding and loop structure formation in the MYC locus in AR-independent PCa cells. a ChIPqPCR analysis using anti-menin to evaluate the binding of menin to the MYC $5^{\prime}$ enhancer $(-67 \mathrm{~kb})$ and promoter in DU145 and PC3 cells treated with siCtrl or siMEN1(1) + (3). Chrl served as a negative control. b ChIP-qPCR analysis using anti-JunD to detect the binding of JunD to the MYC $5^{\prime}$ enhancer and promoter in DU145 and PC3 cells treated with siCtrl or siJunD. c ChIP-qPCR analysis to assess the effect of MEN1-KD on the level of JunD recruitment to the MYC 5' enhancer in DU145 and PC3 cells. $\mathbf{d}$ Primer locations for qPCR of $3 C$ and ChIP-3C analyses. e $3 C$ detection results (DP1-DP2 fragment) and control (CP1-CP2) by PCR in siCtrl or siMEN1(1) + (3)-transfected DU145 cells upon ligation or non-ligation. ChIP-3C qPCR analysis detecting menin ChIP-qPCR analysis showing menin binding $(\mathbf{f})$ and JunD binding $(\mathbf{g})$ to the MYC $5^{\prime}$ enhancer, MYC promoter and the looping fragment (F3-F6) in DU145 cells transfected with siCtrl or siMEN1(1) + (3) under ligation (right panel) or non-ligation (left panel) conditions, P1-P2 and P7-P8 were used as negative controls. Representative blots of three independent experiments

\section{Reduced menin expression triggers the nuclear translocation of JunD in AR-independent PCa cells}

One factor in particular, the proto-oncogene JunD, was recently reported to promote the proliferation of $\mathrm{PCa}$ cells through MYC signaling [8]. To better understand this mechanism, we investigated the distinct effects of MEN1-KD in AR-dependent and -independent PCa cells using MI503 as a means of comparison, since MI503 is known to inhibit not only the interaction between menin and MLL, but also that of menin and JunD [38]. Indeed, we previously demonstrated that MI503 treatment inhibited the proliferation of both types of PCa cell lines, unlike siMEN1 treatment [23]. Hence, we initially performed foci formation assays to confirm a significant decrease in colony formation in both AR-dependent and AR-independent PCa cells upon MI503 treatment (Fig. 2a-b). To understand the molecular differences triggered by siMEN1 and MI503, we examined the expression of MYC and JunD. The expression of MEN1, MYC and JunD was lower in all MI503-treated PCa cells at the mRNA (Fig. 2c and Fig. S2a) and protein levels (Fig. 2d). However, following MEN1-KD, only AR-dependent (LNCaP and 22Rv1) cells displayed a decrease in mRNA (Fig. 2e and S2b) and protein levels (Fig. 2f and S2c). Indeed, AR-independent PCa cells remained unaffected by this treatment (Fig. 2e-f and S2b-c), indicating that MI503 suppresses cell growth by inhibiting menin and JunD expression in PCa cells. Consequently, we confirmed the positive role of JunD on cell proliferation in JunD-KD DU145 and PC3 cells (Fig. S2d). We further evaluated JunD protein expression in MEN1-KD DU145 and PC3 cells, and found that, although MEN1 silencing did not affect the JunD expression at the transcriptional (Fig. 2e and S2b, lower panel) and total protein levels (Fig. $2 \mathrm{f}$ and S2c), it triggered the nuclear translocation of JunD in these AR-independent PCa cells (Fig. 2g-h and S2e), indicative of JunD activation [39]. Conversely, JunD silencing did not lead to any change in menin expression (Fig. S2f-g).

\section{MEN1 knockdown enhances the binding of JunD to the MYC locus in AR-independent PCa cells}

Wang et al. identified four potential AP-1 binding sites in a 5' MYC enhancer, situated $67 \mathrm{~kb}$ upstream of the transcription start site (TSS) of $M Y C$, and demonstrated the binding of JunD to the enhancer to regulate $M Y C$ transcription in breast cancer cells [40]. We wondered whether the activation of JunD may allow the maintenance of $M Y C$ transcription in MEN1-KD ARindependent PCa cells. Through ChIP-qPCR analyses, we observed that menin bound to the $M Y C$ promoter and to its $5^{\prime}$ enhancer in DU145 and PC3 cells (Fig. 3a), while JunD bound only to the MYC 5' enhancer (Fig. $3 \mathrm{~b})$. We then hypothesized that the increased JunD nuclear translocation triggered by MEN1 silencing may augment its binding to the 5' $M Y C$ enhancer, which we confirmed by ChIP analysis upon MEN1-KD in DU145 and PC3 cells (Fig. 3c).

Next, we performed $3 \mathrm{C}$ assays to determine whether reduced menin expression modulates the "loop" structure between the distal enhancer region and the proximal promoter region [40]. For the $3 \mathrm{C}$-PCR reaction, we amplified a $330 \mathrm{bp}$ DNA fragment ("Detection fragment") to assess intramolecular ligation of the looping between the enhancer and promoter of the MYC locus, using the forward primer (DP1) that anneals upstream of the distal enhancer and the reverse primer (DP2) that anneals downstream from the Fat I site in the MYC promoter (Fig. 3d). As shown in Fig. 3e and Fig. S3a, the detection fragment increased in MEN1-KD cells under the ligation condition, compared to siCtrl cells. As expected, the detection fragment failed to yield products in $3 \mathrm{C}$ assays under the non-ligation condition. This analysis clearly demonstrates that reduced menin expression triggers increased loop formation between the $M Y C$ enhancer and proximal promoter in DU145 and PC3 cells.

We then performed ChIP-3C [41] to further determine how the loop formed between the $M Y C$ enhancer and proximal promoter [42] might change in MEN1-KD ARindependent $\mathrm{PCa}$ cells. In the non-ligation condition, menin bound to the enhancer and promoter of the $M Y C$ locus (Fig. 3f and S3b, left panels), and JunD bound only to the $5^{\prime}$ MYC enhancer in DU145 and PC3 cells (Fig. $3 \mathrm{~g}$ and $\mathrm{S} 3 \mathrm{c}$, left panels), while, in the ligation condition, both menin and JunD could be detected on the $5^{\prime} M Y C$ enhancer and proximal promoter, as well as on the intramolecular ligation region (P3-P6), suggesting that they bound together to the looping structure (Fig. 3f-g 
$\mathbf{a}$
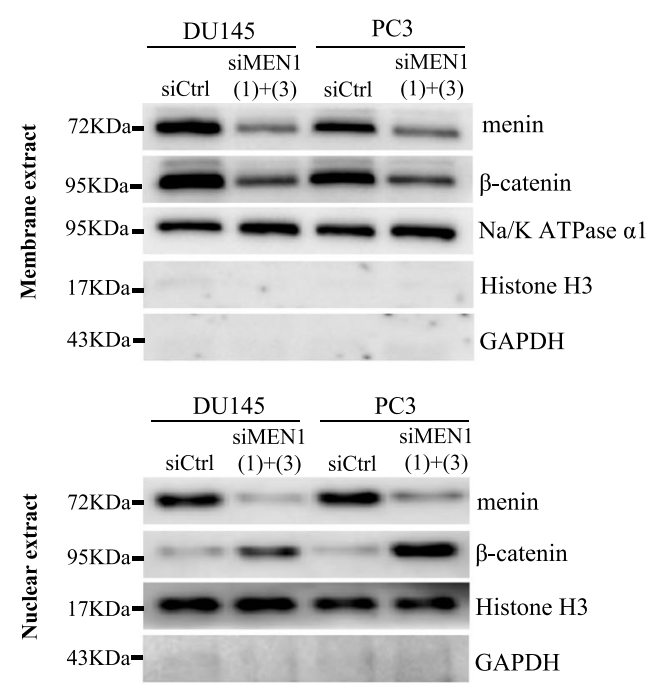

b
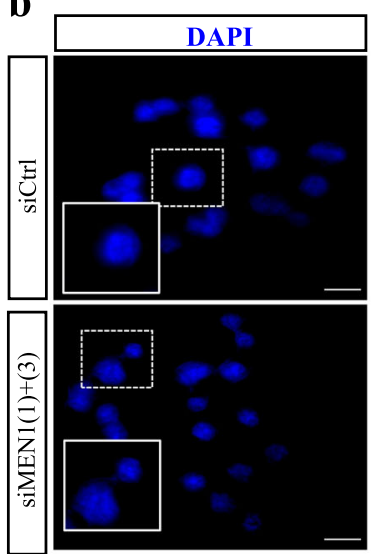

c

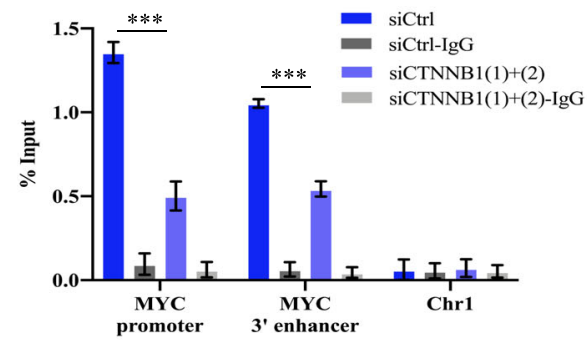

d

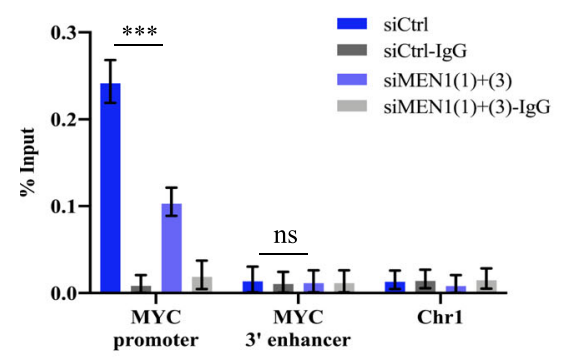

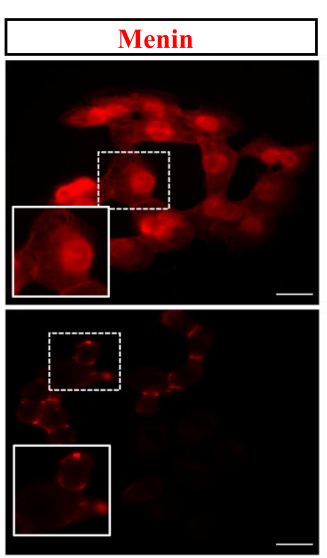

e

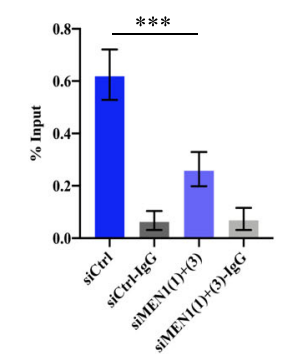

f

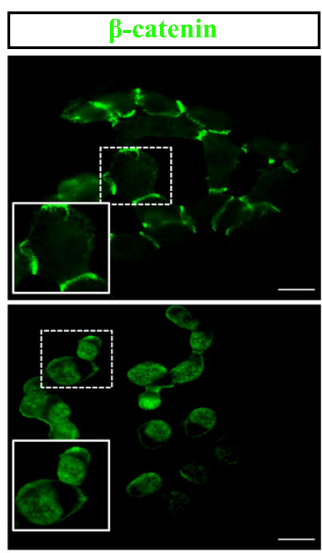

DU145, 1st ChIP:menin

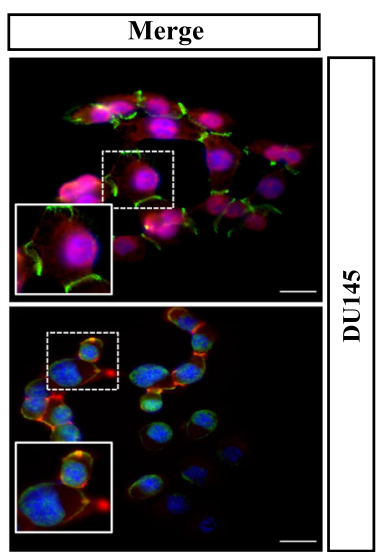

DU145, reChIP: $\beta$-catenin

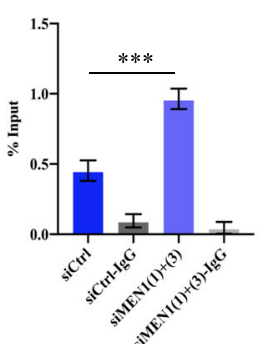

DU145, reChIP: $\beta$-catenin
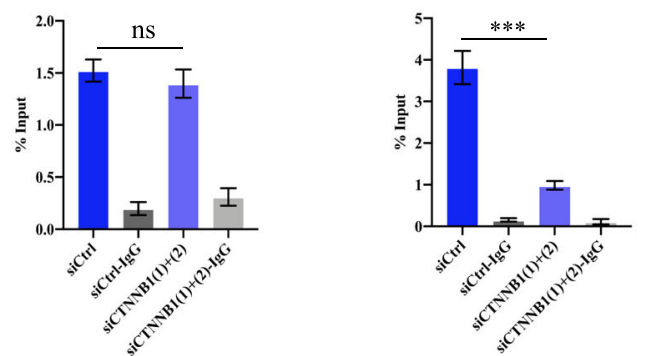

Fig. 4 (See legend on next page.) 
(See figure on previous page.)

Fig. 4 MEN1 silencing results in nuclear translocation of $\beta$-catenin and an increase in its binding to the MYC promoter in AR-independent $P C a$ cells. a Western blot analysis of $\beta$-catenin expression in different subcellular fractions in siCtrl or siMEN1 (1) + (3)-treated DU145 and PC3 cells as indicated. b Double IF staining showing menin and $\beta$-catenin in siCtrl or siMEN1(1) + (3)-treated DU145 cells. Scale bar $=25 \mu \mathrm{m}$. ChIP-qPCR analysis assessing $\beta$-catenin (c) or menin (d) binding to the MYC promoter and the MYC 3'enhancer in siCtrl or siMEN1(1) + (3)-treated DU145 cells. reChIP analysis evaluating the effect of MEN1-KD (e) and CTNNB1-KD (f) on menin (left panel) and $\beta$-catenin (right panel) co-occupancy on the MYC promoter in DU145 cells. Representative blots of three independent experiments

and S3b-c, right panels). Interestingly, JunD binding increased at the intramolecular ligation region (P3-P6) of the MYC locus in MEN1-KD DU145 and PC3 cells under the ligation condition (Fig. $3 \mathrm{~g}$ and $\mathrm{S} 3 \mathrm{c}$, right panels). These results provide first evidence that menin is present within the corresponding chromatin loop structure between the $M Y C$ enhancer and promoter, and that, importantly, its inactivation leads to increased binding of JunD to the $5^{\prime} M Y C$ enhancer and the loop structure. Taken together, our analyses strongly suggest that JunD, through its nuclear translocation, replaces menin on the $M Y C$ locus to maintain $M Y C$ transcription in MEN1-KD AR-independent PCa cells.

\section{MEN1 silencing triggers the nuclear translocation of $\beta$ - catenin in AR-independent PCa cells}

Our previous works highlighted the activation of $\beta$ catenin, a menin-interacting protein, upon Men 1 disruption in mouse insulinoma [43, 44]. Moreover, $\beta$-catenin is a well-known oncogene in prostate cancer cells [45]. We, therefore, also analyzed the expression of $\beta$-catenin in MEN1-KD PCa cells, and found that MEN1 silencing resulted in the accumulation of $\beta$-catenin in the nucleus of DU145 and PC3 cells, with its membrane and cytoplasmic expression being markedly reduced (Fig. 4a-b and Fig. S4a). Conversely, MEN1-KD significantly downregulated $\beta$-catenin total protein and cytoplasmic fraction levels in LNCaP cells and 22Rv1 cells, whereas its expression in nuclear and membrane subcellular fractions remained unaltered (Fig. S 4 b-d). However, CTNNB1 silencing did not result in any change in menin expression (Fig. S 4 e). Furthermore, we confirmed the positive role of $\beta$-catenin in cell proliferation in DU145 and PC3 cells knocked-down for CTNNB1 coding for $\beta$ catenin (Fig. S4f). Collectively, these results indicate that, in MEN1-KD AR-independent $\mathrm{PCa}$ cells, the nuclear translocation of $\beta$-catenin is drastically increased, a hallmark of the activation of the WNT signaling pathway [46].

\section{MEN1 inactivation increases $\beta$-catenin binding to the MYC promoter in AR-independent PCa cells}

It has previously been reported that MYC and $\beta$-catenin have a strong cooperative action in different cancers [47-49]. We thus investigated the eventual interplay between menin and $\beta$-catenin in regulating MYC expression in AR-independent PCa cells. Our ChIP analyses showed that $\beta$-catenin bound to the MYC promoter and its $3^{\prime}$ enhancer, formerly described in colon cancer cells [48] (Fig. 4c and S5a), while menin bound to the promoter, but not to the $M Y C 3^{\prime}$ enhancer in DU145 and PC3 cells (Fig. 4d and S 5b). Furthermore, ChIP-reChIP and ChIP analyses showed that MEN1-KD enhanced $\beta$-catenin binding to the $M Y C$ promoter (Fig. $4 \mathrm{e}$ and $\mathrm{S} 5 \mathrm{c}$ ), but not its binding to the MYC 3 ' enhancer (Fig. S5d) in DU145 and PC3 cells, whereas CCTNB1$\mathrm{KD}$ did not affect the binding of menin to the $M Y C$ promoter in DU145 and PC3 cells (Fig. 4f and S5e). These analyses indicate that nuclear translocation of $\beta$-catenin allows the maintenance of $M Y C$ transcription in MEN1KD AR-independent PCa cells.

\section{JunD and $\beta$-catenin are critical for the tumorigenic potential of AR-independent PCa cells and the expression of EMT markers}

To further investigate the role of JunD and $\beta$-catenin in AR-independent PCa cells, we initially performed soft agar assays to assess the anchorage independence in JunD-KD or CTNNB1-KD PCa cells. Both JunD-KD (Fig. 5a) and CTNNB1-KD (Fig. 5b) resulted in a significant decrease in colony formation in DU145 and PC3 cells. Concomitantly, JunD-KD (Fig. 5c-d) and CTNNB1KD (Fig. 5e-f) upregulated mRNA and protein levels of the epithelial marker E-cadherin in DU145 and PC3 cells. Consistently, a marked decreased in mRNA and protein expression of Twist 1, a repressor of E-cadherin gene transcription and a known regulator of EMT [50], was observed. Importantly, the expression of HIF-1 $\alpha$, a key mediator in EMT, inflammation and tumorigenesis under hypoxic conditions [51-53], was also reduced in JunD-KD and CTNNB1-KD DU145 and PC3 cells. These findings indicate that JunD and $\beta$-catenin are critical for the tumorigenic potential and the expression of EMT markers in AR-independent PCa cells.

The activation of JunD and $\beta$-catenin is needed to reverse the oncosuppressive role of menin in AR-independent PCa cells

We then proceeded to further determine the specific roles of JunD and $\beta$-catenin in MEN1-KD ARindependent $\mathrm{PCa}$ cells. To this end, we used the foci formation assay to evaluate cell growth upon transfection 
a

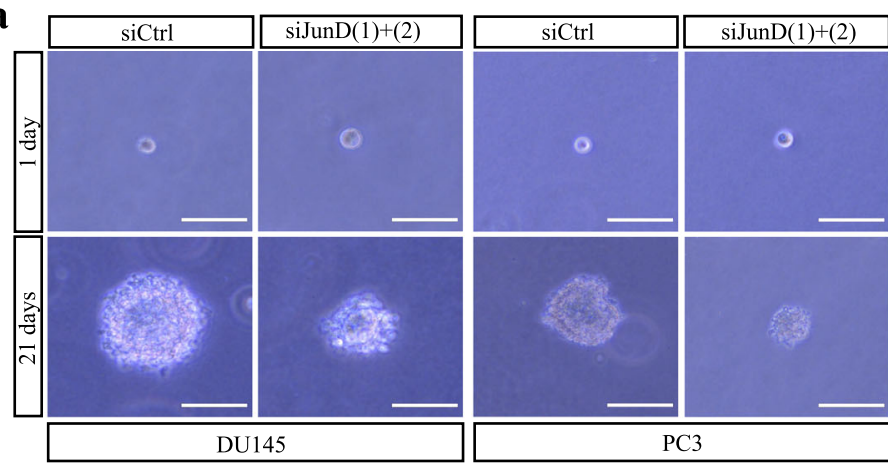

b

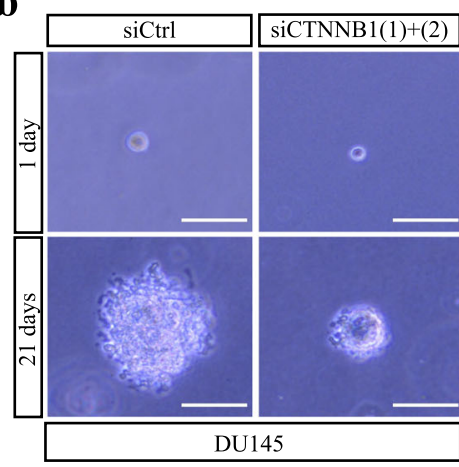

c

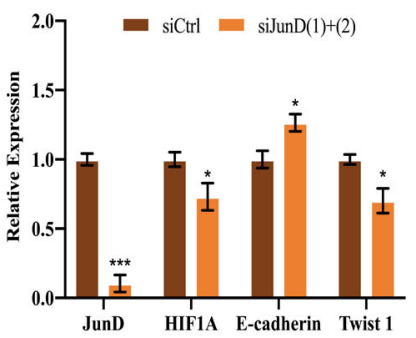

e

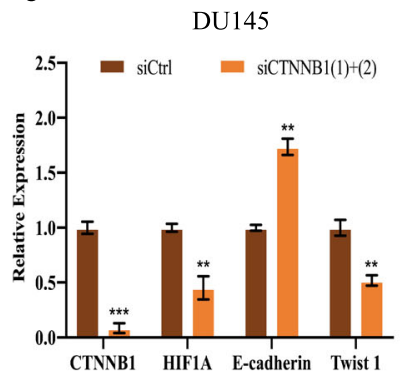

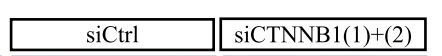

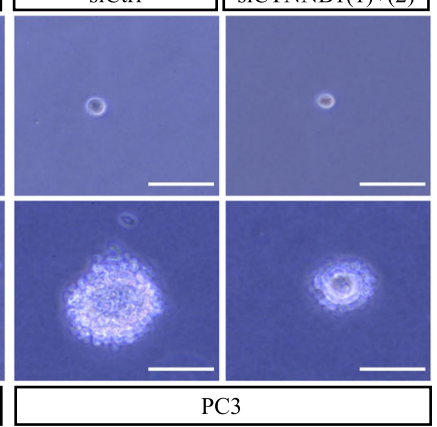

PC3
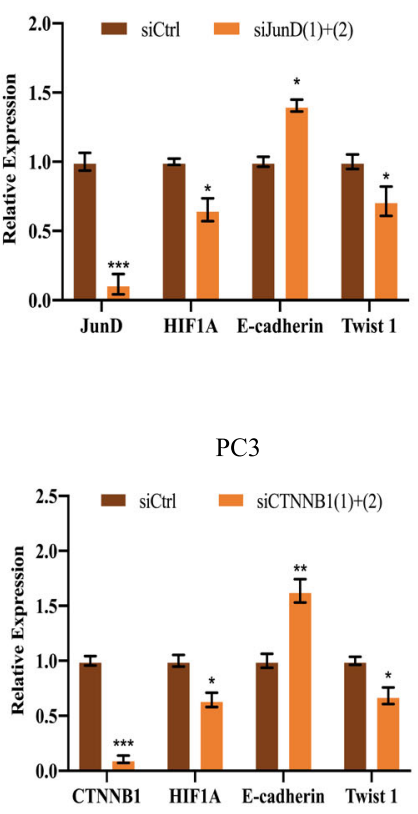
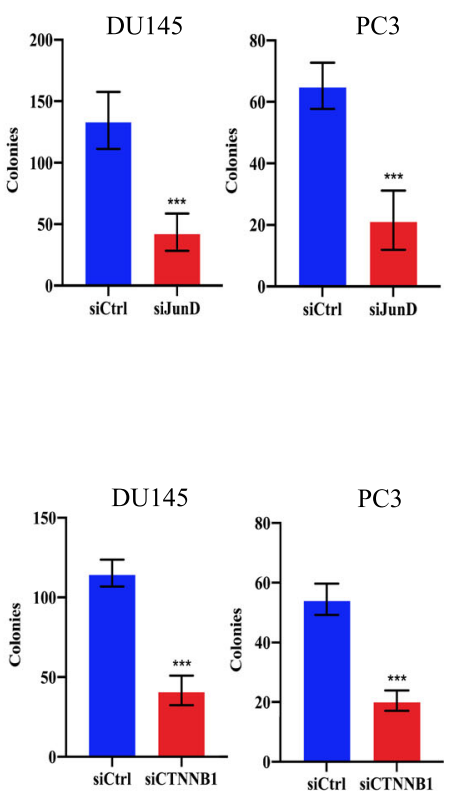

d $\quad \frac{\mathrm{DU} 145}{\text { siCtrl }}$ siJunD $\frac{\mathrm{PC} 3}{\text { siCtrl }}$ siJunD

$43 \mathrm{KDa}-$

$130 \mathrm{KDa}=\mathrm{HIF-1 \alpha}$

$130 \mathrm{KDa}-$

$26 \mathrm{KDa}-\longrightarrow$ Twist 1

$43 \mathrm{KDa}=\longrightarrow \mathrm{GAPDH}$

f $\quad$ DU145 $\quad$ PC3 siCtrl siCTNNB1 siCtrl siCTNNB1

95KDa $-\longrightarrow+\cdots+\beta$-catenin

130KDa $-\quad$ HIF-1a

130KDa -

${ }^{26 \mathrm{KDa}}-\infty-\mathrm{Twist}$

${ }_{43 \mathrm{KDa}-}^{-}-\mathrm{GAPDH}$ 
(See figure on previous page.)

Fig. 5 JunD and $\beta$-catenin are involved in the regulation of EMT marker expression in AR-independent PCa cells. Representative images of soft agar colony formation assay in JunD-KD (a, left panel) and CTNNB1-KD (b, left panel) DU145 or PC3 cells. Scale bar $=50 \mu \mathrm{m}$. Graphs showing quantitative analysis of colony formation at 21 days post-transfection with siCtrl or siJunD(1) + (2) using Image J software (right panel). qRT-PCR (c) and Western blot (d) analyses of mRNA and protein expression of HIF-1a, E-cadherin and Twist 1 in JunD-KD DU145 and PC3 cells. qRT-PCR (e) and Western blot (f) analyses of mRNA and protein expression of HIF-1a, E-cadherin and Twist 1 in CTNNB1-KD DU145 and PC3 cells DU145 and PC3 cells. Representative blots of three independent experiments

with siMEN1, siJunD, siCTNNB1, siMEN1 + siJunD, siMEN1 + siCTNNB1 or siMEN1 + siJunD+siCTNNB1 in DU145 (Fig. 6a) and PC3 (Fig. S6a) cells. Knockdown of JunD or CTNNB1 significantly abolished the effect of $M E N 1-K D$, whereas reduced menin expression significantly reversed the effects of JunD-KD or CTNNB1-KD in DU145 and PC3 cells (Fig. 6a and S6a). We obtained similar results on cell proliferation by Incucyte ZOOM analysis (Fig. S6b).

Having shown that both JunD and $\beta$-catenin activation are crucial for cell growth in MEN1-KD DU145 and PC3 cells, we hypothesized that MEN1 silencing also alters the expression of genes promoting EMT in ARindependent PCa cell lines. As expected, MEN1-KD in DU145 and PC3 cells led to reduced E-cadherin expression at the mRNA and total protein levels (Fig. 6c-d). Moreover, this silencing led to an increase in the expression of HIF-1 $\alpha$, Vimentin and BMI1 at the transcript and total protein levels in these cells, as well as the nuclear accumulation of HIF- $1 \alpha$, Twist 1 and BMI1 (Fig. 6c-d). These results suggest that menin could be a key factor inhibiting the molecular program favoring EMT in AR-independent PCa cells.

Having detected the increased tumorigenic potential and altered expression of several known EMT and stemness markers in MEN1-KD AR-independent cells, we overexpressed menin in these cells, in order to further validate our observations. Interestingly, menin overexpression in these cells led to reduced colony formation and cell migration (Fig. S7a-b), and increased expression of E-cadherin and reduced expression of Vimentin, HIF$1 \alpha$ and Twist1 (Fig. 6e-f).

Importantly, we performed cell line-derived xenografts under mouse kidney capsule using PC3-GFP cells to validate our data in vivo (Fig. S 8 a). Following the transplantation of PC3-GFP cells, mice were treated with either MI503 $(n=11)$ or vehicle $(n=9)$ for 1 month. We observed that MEN1 and JunD inhibition with MI503 gave rise to significantly accelerated tumor growth, compared to the control treatment (Fig. 7a-b). Morphologically, MI503-treated PC3-GFP cells appeared more variable in size and more invasive towards surrounding mouse tissues, with disorientated alignment (Fig. 7a, c, S8b). In agreement with our in vitro observation, $\mathrm{qPCR}$ and immunostaining analyses of PC3-GFP xenografts confirmed reduced expression of menin and JunD in xenografted cells, but revealed increased CTNNB1 transcription and overt nuclear expression of $\beta$-catenin in MI503-treated-PC3GFP cells (Fig.7c-d, S8c-d), suggesting that inhibition of both menin and JunD could still lead to aggravated tumorigenic potential of xenografted PC3-GFP cells, due to activated $\beta$-catenin.

In parallel, a significant negative correlation between MEN1 and CTNNB1 mRNA expression was seen in two different datasets from TCGA database [35] and mCRPC database [36] (Fig. 7e). These data further support the activated $\beta$-catenin due to MI503 treatment observed in PC3-GFP xenografts.

Overall, our data suggest that the activation of both JunD and $\beta$-catenin, although they individually play critical roles, is required to produce the effects of menin inactivation in AR-independent PCa cells (Fig. 7f).

\section{Discussion}

In the present study, we uncovered a previously unknown role for menin in preventing AR-independent $\mathrm{PCa}$ cells from acquiring an aggravated tumorigenic potential, contrasting drastically with its oncogenic role in AR-dependent PCa cells [23]. More importantly, we demonstrated that MEN1 silencing in AR-independent PCa cells led to nuclear translocation and, therefore, increased binding of JunD and $\beta$-catenin to the regulatory sequences of the $M Y C$ gene, leading to maintained MYC expression and prominent cellular and molecular alterations.

MEN1-KD resulted in an even greater increase in the tumorigenic potential of DU145 and PC3 cells, wellknown tumorigenic cell lines, including a marked loss of contact-inhibition, augmented cell anchorage independence and cell migration. Importantly, in vivo xenograft tests in mice further demonstrated that PC3-GFP cells treated with MI503 gave rise to significantly increased tumor growth. In parallel, we noticed that the changes in cellular behavior were accompanied by remarkable alterations in the expression of EMT makers, including BMI1, Twist1, HINF-1 $\alpha$, E-Cadherin and Vimentin. Our data thus suggest that MEN1 silencing in ARindependent $\mathrm{PCa}$ cells affects cell proliferation, cell differentiation and cell migration, resulting in altered cell 


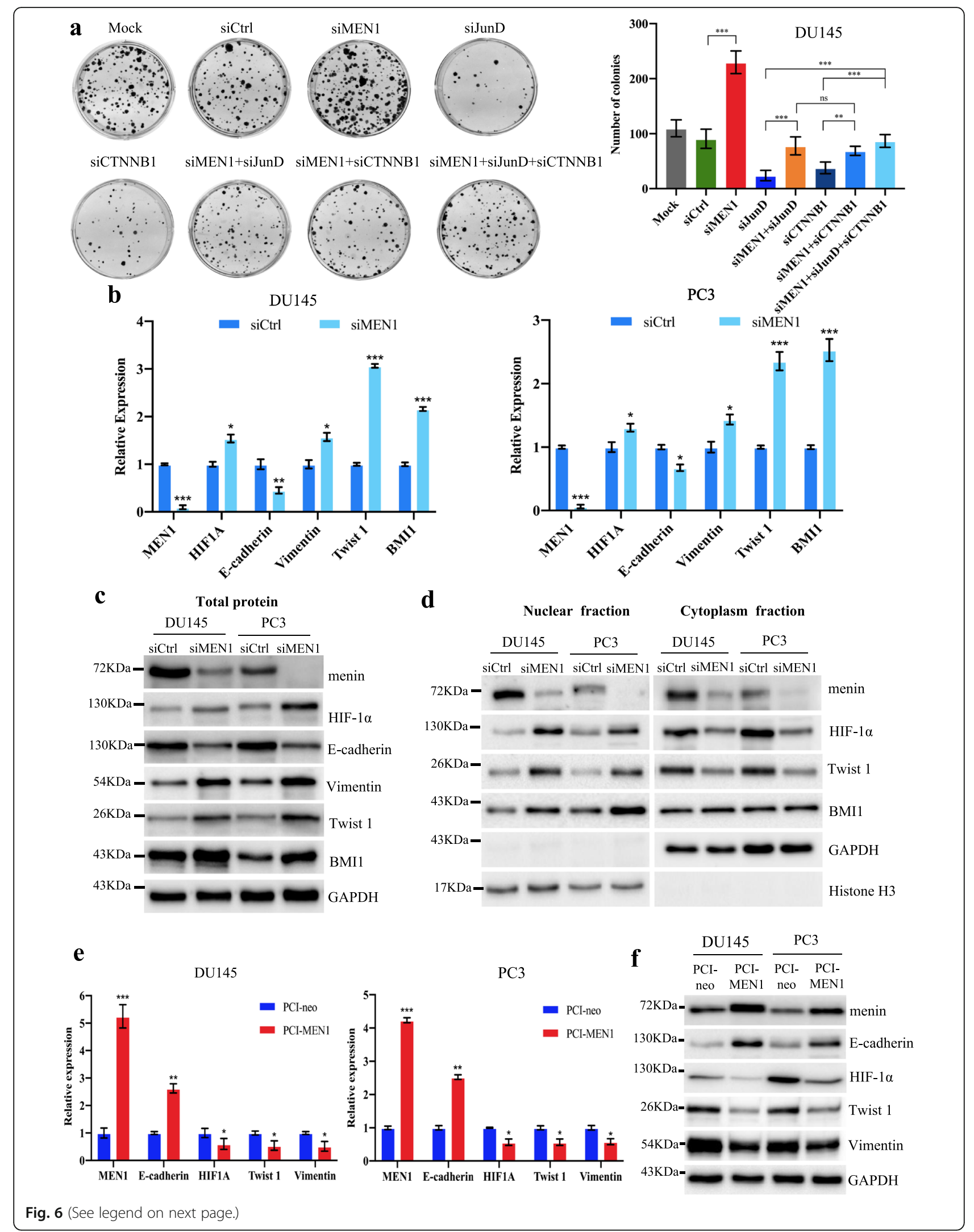


(See figure on previous page.)

Fig. 6 The expression of both JunD and $\beta$-catenin is critical for the tumorigenic potential of AR-independent $P C a$ cells. a Representative images of foci formation of DU145 cells upon transfection with siMEN1, siJunD, siCTNNB1, siMEN1 + siJunD, siMEN1+ siCTNNB1 or siMEN1 +

siJunD+siCTNNB1. Quantification of data is shown in the right and lower panel. $\mathbf{b}$ qRT-PCR analysis showing mRNA expression of HIF-1a, Ecadherin, Vimentin, Twist 1 and BMI1 in DU145 and PC3 cells transfected with siCtrl or siMEN1(1) + (3). c Western blot analysis showing total protein expression of menin, HIF-1a, E-cadherin, Vimentin, Twist 1 and BMI1 in DU145 and PC3 cells transfected with siCtrl or siMEN1(1) + (3). d Western blot analysis showing menin, HIF-1a, Vimentin, Twist 1 and BMI1 expression in nuclear and cytoplasmic subcellular fractions in siCtrl or siMEN1(1) + (3)-treated DU145 and PC3 cells. Representative blots of three independent experiments. e qRT-PCR analysis of mRNA expression of E-cadherin, HIF-1a, Twist 1 and Vimentin in PCI-neo or PCI-MEN1-transfected DU145 and PC3 cells. f Western blot analysis of E-cadherin, HIF-1a, Twist 1 and Vimentin protein expression in DU145 and PC3 cells transfected with PCI-neo or PCI-MEN1 as indicated. Representative blots of three independent experiments

plasticity and increased tumorigenicity. Both the changes in cell plasticity and abnormal expression of EMT markers are largely documented in PCa, in particular in clinical mCRPC samples [8]. However, we highlighted, for the first time, the involvement of menin in these procedures specifically in AR-independent PCa cells.

JunD was the first menin-interacting partner identified after the identification of the MEN1 gene, with its possible oncogenic role upon menin inactivation being proposed from the beginning [54]. The hypothesis was further strengthened by menin 3D structure analysis, showing that JunD binds to the same menin protein pocket as KMT2A/B [16]. However, the detailed molecular mechanisms underlying the role of JunD in MEN1 tumors has never been clarified. Interestingly, Wasylishen et al. recently reported that menin plays a tumor suppressive role in mouse Ras-related pancreatic cancer, likely through the activated JunD [55]. It is worth mentioning that our finding is in total agreement with the recent work reporting the role played by JunD in PCa through MYC regulation [8]. Importantly, our data provide new mechanisms showing that MEN1 silencing led to the prominent nuclear translocation of JunD, which resulted not only in its increased binding to the regulatory sequence of the $M Y C$ locus, thus maintain MYC expression, but also in the altered expression of EMT markers, contributing to the aggravated tumorigenic potential seen in these MEN1-KD AR-independent PCa cells.

The activation of $\beta$-catenin and the WNT signaling pathway is considered to be among the most commonly occurring molecular alterations involved in the development and progression of $\mathrm{PCa}[56,57]$. It has also been suggested that $\beta$-catenin could play a critical role in ARindependent CRPC [58]. We and our collaborators have previously demonstrated that menin physically interacts with $\beta$-catenin, and that Men1 deficiency leads to nuclear translocation and activation of the latter in mouse Men1 insulinoma [43, 44]. Interestingly, we uncovered in the current study that, in AR-independent PCa cells, a similar molecular switch can also occur, accompanied by decreased E-Cadherin and increased Vimentin expression, reminiscent of increased EMT. It is worth mentioning that similar changes were observed in mouse Men1 insulinomas and mouse Men1 mammary lesions $[59,60]$. Furthermore, our ChIP analyses demonstrated an increase in the binding of $\beta$-catenin to the $M Y C$ promoter, contributing to maintaining MYC expression in these cells. Importantly, the fact that the nuclear expression of $\beta$-catenin increased in MI503-treated xenografted PC3-GFP cells further demonstrates that $\beta$-catenin activation is critical for aggravated tumorigenicity triggered by menin inactivation observed in the current work.

Notably, we have depicted the increased nuclear expression of several factors related to cell dedifferentiation, including BMI1, Twist1 and HIF- $1 \alpha$. These factors are known to interact with both the JunD and $\beta$-catenin pathways and to play relevant roles in cancer progression [61-63]. Based on the published data, we could hypothesize that the activation of JunD and $\beta$-catenin may initially lead to the activation of HIF- $1 \alpha$. The latter could subsequently trigger the activation of other factors as previously described [64-67]. The interplay between menin inactivation and the altered expression of EMT makers revealed in the current study may explain the altered cellular activities observed, and it would be relevant to study whether similar situations could occur during $\mathrm{PCa}$ progression, especially in the DNPC subtype of $\mathrm{mCRPC}$.

Our study may also provide insight into novel strategies for AR-independent PCa treatment, if these molecular perturbations could be further confirmed in clinical studies. Considering the data obtained from the current work, especially the above mentioned in vivo test, caution should be taken when using inhibitors of menin/MLL interaction, like MI503, in PCa therapeutic assays, especially in mCRPC cases.

\section{Conclusion}

The present work unveiled the activation of the JunD and $\beta$-catenin pathways upon menin inactivation 

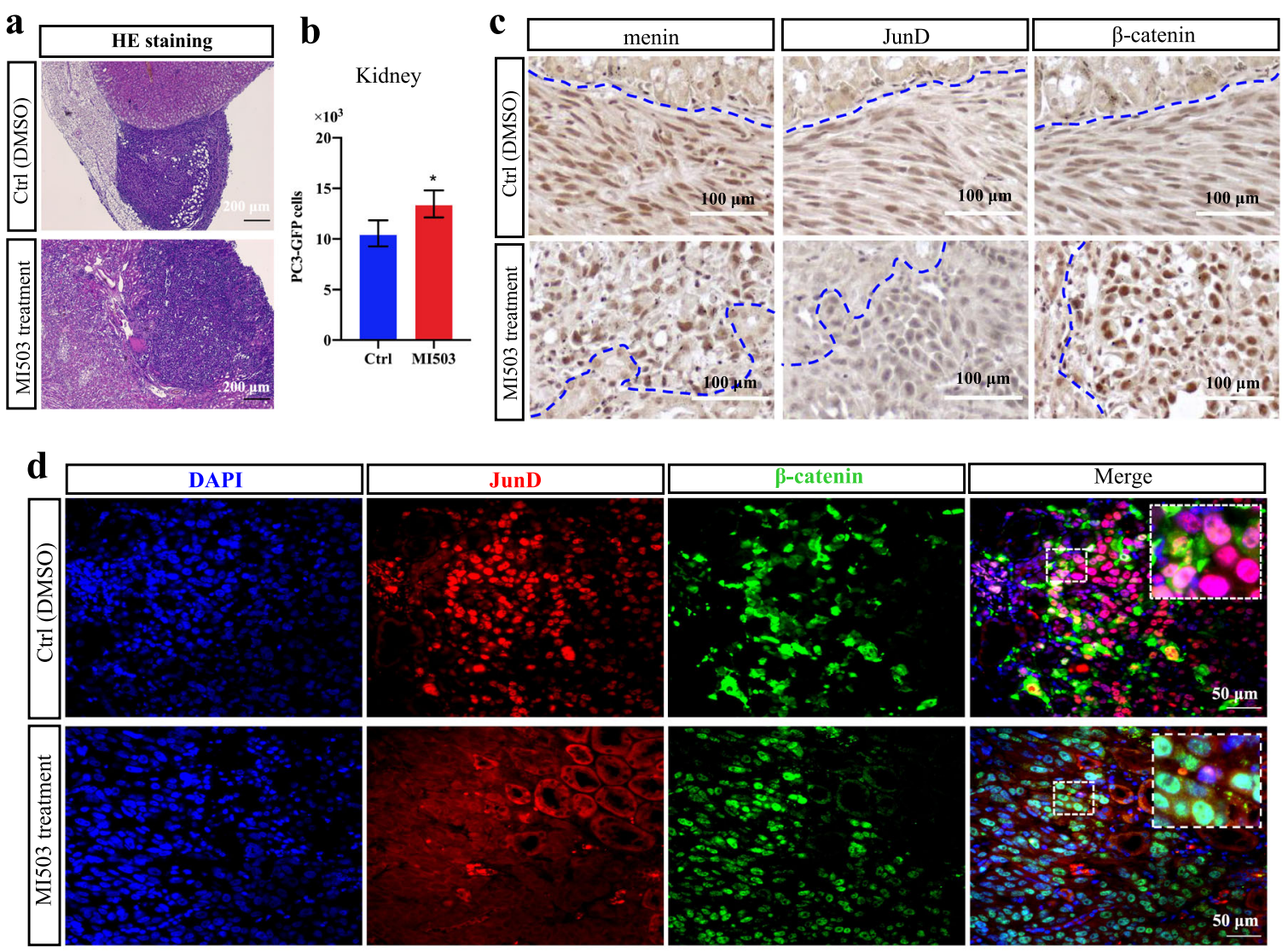

$\mathbf{e}$

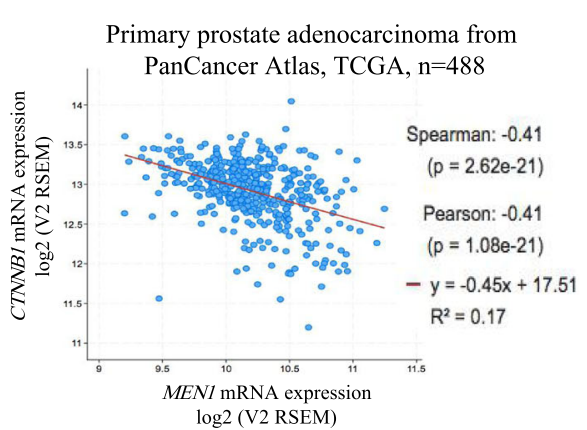

mCRPC SU2C/PCF Dream Team, PNAS 2019, $\mathrm{n}=208$

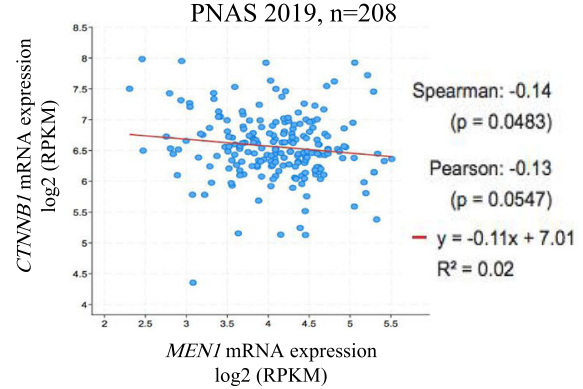

Fig. 7 (See legend on next page.) f

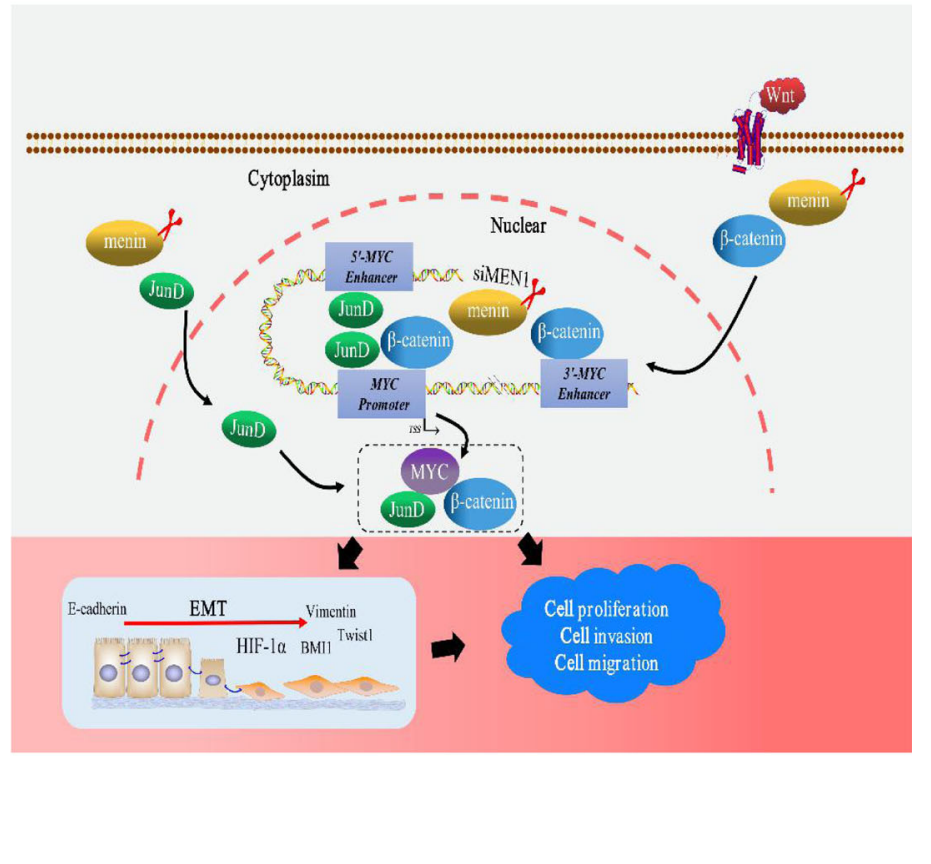


(See figure on previous page.)

Fig. 7 MI503-treated PC3-GFP xenografts display increased tumor growth with nuclear overexpression of $\beta$-catenin. a Representative images of HE stained xenografts treated with DMSO (upper) and MI503 (lower). Scale bar $=200 \mu \mathrm{m}$. b qRT-PCR analysis evaluating the number of PC3-GFP cells transplanted in mouse kidney treated $(n=11)$ or not $(n=9)$ with MI503. Representative images of IHC staining $(\mathbf{c}$, Scale bar $=100 \mu \mathrm{m})$ for menin, JunD and $\beta$-catenin or IF staining $(\mathbf{d}$, Scale bar $=50 \mu \mathrm{m})$ for JunD and $\beta$-catenin in xenografts in the Ctrl group (DMSO treatment, upper panels) or MI503 treatment group (lower panels) as indicated. e Data mining analyses investigating the clinical correlation between MEN1 and CTNNB1 mRNA expression in primary prostate cancer (left panel) and mCRPC (right panel) using existing prostate cancer datasets. $\mathbf{f}$ Schematic summary of oncosuppressive functions of menin in AR-independent PCa cells. Representative blots of three independent experiments

specifically in AR-independent cells. Of note, the oncosuppressive role of menin in AR-independent PCa cells is closely associated with maintained MYC expression and altered expression of EMT markers (Fig. 7f), which may pave the way for new strategies for $\mathrm{PCa}$ treatment.

\section{Supplementary Information}

The online version contains supplementary material available at https://doi. org/10.1186/s13046-021-02058-7.

Additional file 1. Supplementary Materials and Methods.

Additional file 2 .

\section{Acknowledgements}

We are grateful to Brigitte MANSHIP for her assistance in editing and proofreading the manuscript, Zhi Chong Wu for his scientific and technical input.

\section{Authors' contributions}

Y.L. conducted the experiments, analyzed and interpreted the data, prepared figures and manuscript; V.V. provided technical and material support and participated in the study design, data interpretation and manuscript preparation; S.B. and SD conducted mouse xenograft model tests, participated in analyses of xenografts and data interpretation; M.L.R and C.X.Z conceived and supervised the study and manuscript preparation, and obtained funding. The author(s) read and approved the final manuscript.

\section{Funding}

This study was supported by the Ligue Inter-Régionale contre le Cancer (R19040CC), and the Association: «Le Cancer du sein, parlons-en». Y. L was the recipient of a PhD-fellowship from the China Scholarship Council.

\section{Availability of data and materials}

The authors confirm that the data supporting the findings of this study are available within the article [and/or] its supplementary materials.

\section{Declarations}

\section{Ethics approval and consent to participate}

All animal experiments were performed in accordance with the animal care guidelines of the European Union and were validated by the local Animal Ethics Evaluation Committee in agreement with the French Ministry of High School and Research. All experiments were approved by Auvergne Ethics Committee (CEMEAA) and registered according the approval number 17296 2018102216428025 v3

\section{Consent for publication}

All of the authors approved the contents and the data in this manuscript and agreed for its submission for publication.

\section{Competing interests}

The authors declare that they have no competing interest.

\section{Author details}

${ }^{1}$ Université Lyon, Université Claude Bernard Lyon 1, INSERM 1052, CNRS 5286 , Centre Léon Bérard, Centre de recherche en cancérologie de Lyon, 69008 Lyon, France. ${ }^{2}$ Centre de biologie Sud, Hôpital Lyon Sud, Hospices Civils de Lyon, 69310 Pierre-Bénite, France. ${ }^{3}$ Université Clermont Auvergne, GReD, CNRS UMR 6293, INSERM U1103, 28 Place Henri Dunant, BP38, 63001 Clermont-Ferrand, France.

Received: 12 May 2021 Accepted: 2 August 2021

Published online: 26 August 2021

\section{References}

1. Sung H, Ferlay J, Siegel RL, Laversanne M, Soerjomataram I, Jemal A, Bray F. Global cancer statistics 2020: GLOBOCAN estimates of incidence and mortality worldwide for 36 cancers in 185 countries. CA Cancer J Clin. 2021; 71(3):209-49.

2. Lonergan PE, Tindall DJ. Androgen receptor signaling in prostate cancer development and progression. J Carcinog. 2011;10:20.

3. Isbarn H, Boccon-Gibod L, Carroll PR, Montorsi F, Schulman C, Smith MR, et al. Androgen deprivation therapy for the treatment of prostate cancer: consider both benefits and risks. Eur Urol. 2009;55(1):62-75. https://doi.org/1 0.1016/j.eururo.2008.10.008

4. Scher HI, Solo K, Valant J, Todd MB, Mehra M. Prevalence of prostate Cancer clinical states and mortality in the United States: estimates using a dynamic progression model. PLoS One. 2015;10(10):e0139440. https://doi.org/10.13 71/journal.pone.0139440.

5. Hoang DT, Iczkowski KA, Kilari D, See W, Nevalainen MT. Androgen receptor-dependent and -independent mechanisms driving prostate cancer progression: opportunities for therapeutic targeting from multiple angles. Oncotarget. 2017;8(2):3724-45. https://doi.org/10.18632/oncotarget.12554.

6. Bluemn EG, Coleman IM, Lucas JM, Coleman RT, Hernandez-Lopez S, Tharakan R, et al. Androgen Receptor Pathway-Independent Prostate Cancer Is Sustained through FGF Signaling. Cancer Cell. 2017;32(4):474-489.e6.

7. Laudato S, Aparicio A, Giancotti FG. Clonal evolution and epithelial plasticity in the emergence of AR-independent prostate carcinoma. Trends Cancer. 2019;5(7):440-55. https://doi.org/10.1016/j.trecan.2019.05.008.

8. Elliott B, Millena AC, Matyunina L, Zhang M, Zou J, Wang G, et al. Essential role of JunD in cell proliferation is mediated via MYC signaling in prostate cancer cells. Cancer Lett. 2019;448:155-67. https://doi.org/10.1016/j.canlet.2 019.02.005.

9. $\quad$ Ge J, Yu W, Li J, Ma H, Wang P, Zhou Y, et al. USP16 regulates castrationresistant prostate cancer cell proliferation by deubiquitinating and stablizing c-Myc. J Exp Clin Cancer Res. 2021;40(1):59. https://doi.org/10.1186/s13046021-01843-8.

10. Hung $C L$, Wang LY, Yu YL, Chen HW, Srivastava S, Petrovics G, et al. A long noncoding RNA connects c-Myc to tumor metabolism. PNAS. 2014;111(52): 18697-702. https://doi.org/10.1073/pnas.1415669112.

11. Morrish F, Isern N, Sadilek M, Jeffrey M, Hockenbery DM. C-Myc activates multiple metabolic networks to generate substrates for cell-cycle entry. Oncogene. 2009;28(27):2485-91. https://doi.org/10.1038/onc.2009.112.

12. Lin CJ, Cencic R, Mills JR, Robert F, Pelletier J. C-Myc and elF4F are components of a feedforward loop that links transcription and translation. Cancer Res. 2008;68(13):5326-34. https://doi.org/10.1158/0008-5472.CAN-075876.

13. Iwata T, Schultz D, Hicks J, Hubbard GK, Mutton LN, Lotan TL, et al. MYC overexpression induces prostatic intraepithelial neoplasia and loss of Nkx3.1 in mouse luminal epithelial cells. PLoS One. 2010;5(2):e9427. https://doi. org/10.1371/journal.pone.0009427. 
14. Pan H, Zhu Y, Wei W, Shao S, Rui X. Transcription factor FoxM1 is the downstream target of c-Myc and contributes to the development of prostate cancer. World J Surg Oncol. 2018;16(1):59. https://doi.org/10.1186/ s12957-018-1352-3.

15. Dardenne E, Beltran H, Benelli M, Gayvert K, Berger A, Puca L, et al. N-Myc induces an $\mathrm{EZH} 2$-mediated transcriptional program driving neuroendocrine prostate Cancer. Cancer Cell. 2016;30(4):563-77. https://doi.org/10.1016/j. ccell.2016.09.005

16. Nyquist MD, Corella A, Coleman I, De Sarkar N, Kaipainen A, Ha G, et al. Combined TP53 and RB1 loss promotes prostate Cancer resistance to a Spectrum of therapeutics and confers vulnerability to replication stress. Cell Rep. 2020;31(8):107669. https://doi.org/10.1016/j.celrep.2020.107669.

17. Ferraldeschi R, Nava Rodrigues D, Riisnaes R, Miranda S, Figueiredo I, Rescigno $P$, et al. PTEN protein loss and clinical outcome from castrationresistant prostate cancer treated with abiraterone acetate. Eur Urol. 2015; 67(4):795-802. https://doi.org/10.1016/j.eururo.2014.10.027.

18. Arora VK, Schenkein E, Murali R, Subudhi SK, Wongvipat J, Balbas MD, et al. Glucocorticoid receptor confers resistance to antiandrogens by bypassing androgen receptor blockade. Cell. 2013;155(6):1309-22. https://doi.org/10.1 016/j.cell.2013.11.012.

19. Boutillon F, Pigat N, Sala LS, Reyes-Gomez E, Moriggl R, Guidotti JE, et al. STAT5a/b deficiency delays, but does not prevent, prolactin-driven prostate tumorigenesis in mice. Cancers (Basel). 2019 Jul 2;11(7):929. https://doi.org/1 0.3390/cancers11070929.

20. Ma $Y$, Zhang $X$, Alsaidan OA, Yang $X$, Sulejmani E, Zha J, et al. Long-chain acyl-CoA Synthetase 4-mediated fatty acid metabolism sustains androgen receptor pathway-independent prostate Cancer. Mol Cancer Res. 2021;19(1): 124-35. https://doi.org/10.1158/1541-7786.MCR-20-0379.

21. Seigne $C$, Fontanière $S$, Carreira $C$, Lu J, Tong WM, Fontanière $B$, et al. Characterisation of prostate cancer lesions in heterozygous Men1 mutant mice. BMC Cancer. 2010;10(1):395. https://doi.org/10.1186/1471-2407-10-395.

22. Malik R, Khan AP, Asangani IA, Cieślik M, Prensner JR, Wang $X$, et al. Targeting the MLL complex in castration-resistant prostate cancer. Nat Med. 2015;21(4):344-52. https://doi.org/10.1038/nm.3830.

23. Teinturier R, Luo Y, Decaussin-Petrucci M, Vlaeminck-Guillem V, Vacherot $F$, Firlej $\mathrm{V}$, et al. Men1 disruption in Nkx3.1-deficient mice results in ARlow/ CD44+ microinvasive carcinoma development with the dysregulated AR pathway. Oncogene. 2021;40(6):1118-27. https://doi.org/10.1038/s41388-02 0-01589-1.

24. Grembecka J, He S, Shi A, Purohit T, Muntean AG, Sorenson RJ, et al. MeninMLL inhibitors reverse oncogenic activity of MLL fusion proteins in leukemia. Nat Chem Biol. 2012;8(3):277-84. https://doi.org/10.1038/nchembio.773.

25. Dreijerink KMA, Groner AC, Vos ESM, Font-Tello A, Gu L, Chi D, et al. Enhancer-mediated oncogenic function of the Menin tumor suppressor in breast Cancer. Cell Rep. 2017;18(10):2359-72. https://doi.org/10.1016/j. celrep.2017.02.025

26. Kigel B, Varshavsky A, Kessler O, Neufeld G. Successful inhibition of tumor development by specific class-3 semaphorins is associated with expression of appropriate semaphorin receptors by tumor cells. PLoS One. 2008;3(9): e3287. https://doi.org/10.1371/journal.pone.0003287.

27. Lukacs RU, Goldstein AS, Lawson DA, Cheng D, Witte ON. Isolation, cultivation and characterization of adult murine prostate stem cells. Nat Protoc. 2010;5(4):702-13. https://doi.org/10.1038/nprot.2010.11.

28. Havens AM, Pedersen EA, Shiozawa Y, Ying C, Jung Y, Sun Y, et al. An in vivo mouse model for human prostate cancer metastasis. Neoplasia. 2008;10(4):371-80. https://doi.org/10.1593/neo.08154.

29. Fontanière $S$, Duvillié $B$, Scharfmann $R$, Carreira $C$, Wang ZQ, Zhang CX. Tumour suppressor menin is essential for development of the pancreatic endocrine cells. J Endocrinol. 2008;199(2):287-98. https://doi.org/10.1677/ JOE-08-0289.

30. Huang F, Chen H, Zhu X, Gong T, Li X, Hankey W, et al. The oncogenomic function of androgen receptor in esophageal squamous cell carcinoma is directed by GATA3. Cell Res. 2020;31(3):362-5. https://doi.org/10.1038/ s41422-020-00428-y.

31. Hagège H, Klous P, Braem C, Splinter E, Dekker J, Cathala G, et al. Quantitative analysis of chromosome conformation capture assays (3CqPCR). Nat Protoc. 2007;2(7):1722-33. https://doi.org/10.1038/nprot.2007.243.

32. Kodama S, Yamazaki $Y$, Negishi M. Pregnane $X$. Receptor represses HNF4a gene to induce insulin-like growth factor-binding protein IGFBP1 that alters morphology of and migrates HepG2 cells. Mol Pharmacol 2015;88(4):746757, DOI: https://doi.org/10.1124/mol.115.099341.
33. Sancho A, Li S, Paul T, Zhang F, Aguilo F, Vashisht A, et al. CHD6 regulates the topological arrangement of the CFTR locus. Hum Mol Genet. 2015; 24(10):2724-32. https://doi.org/10.1093/hmg/ddv032.

34. Gao J, Aksoy BA, Dogrusoz U, Dresdner G, Gross B, Sumer SO, et al. Integrative analysis of complex cancer genomics and clinical profiles using the cBioPortal. Sci Signal. 2013;6(269):pl1. https://doi.org/10.1126/scisignal.2 004088.

35. Abida W, Cyrta J, Heller G, Prandi D, Armenia J, Coleman I, et al. Genomic correlates of clinical outcome in advanced prostate cancer. PNAS. 2019; 116(23):11428-36. https://doi.org/10.1073/pnas.1902651116.

36. Hoadley KA, Yau C, Hinoue T, Wolf DM, Lazar AJ, Drill E, et al. Cell-of-Origin Patterns Dominate the Molecular Classification of 10,000 Tumors from 33 Types of Cancer. Cell. 2018; 173 (2): 291-304.e6.

37. Wu G, Yuan M, Shen S, Ma X, Fang J, Zhu L, et al. Menin enhances C-Mycmediated transcription to promote cancer progression. Nat Commun. 2017; 8(1):15278. https://doi.org/10.1038/ncomms15278.

38. Huang J, Gurung B, Wan B, Matkar S, Veniaminova NA, Wan K, et al. The same pocket in menin binds both MLL and JUND but has opposite effects on transcription. Nature. 2012;482(7386):542-6. https://doi.org/10.1038/na ture10806.

39. Caffarel MM, Moreno-Bueno G, Cerutti C, Palacios J, Guzman M, MechtaGrigoriou F, et al. JunD is involved in the antiproliferative effect of Delta9tetrahydrocannabinol on human breast cancer cells. Oncogene. 2008;27(37): 5033-44. https://doi.org/10.1038/onc.2008.145.

40. Wang C, Mayer JA, Mazumdar A, Fertuck K, Kim H, Brown M, et al. Estrogen induces c-myc gene expression via an upstream enhancer activated by the estrogen receptor and the AP-1 transcription factor. Mol Endocrinol. 2011; 25(9):1527-38. https://doi.org/10.1210/me.2011-1037.

41. Fullwood MJ, Ruan Y. ChIP-based methods for the identification of longrange chromatin interactions. J Cell Biochem. 2009;107(1):30-9. https://doi. org/10.1002/jcb.22116

42. Cai S, Lee CC, Kohwi-Shigematsu T. SATB1 packages densely looped, transcriptionally active chromatin for coordinated expression of cytokine genes. Nat Genet. 2006:38(11):1278-88. https://doi.org/10.1038/ng1913.

43. Cao Y, Liu R, Jiang X, Lu J, Jiang J, Zhang C, et al. Nuclear-cytoplasmic shuttling of menin regulates nuclear translocation of $\beta$-catenin. Mol Cell Biol. 2009;29(20):5477-87. https://doi.org/10.1128/MCB.00335-09.

44. Jiang $X$, Cao Y, Li F, Su Y, Li Y, Peng Y, et al. Targeting $\beta$-catenin signaling for therapeutic intervention in MEN1-deficient pancreatic neuroendocrine tumours. Nat Commun. 2014;5(1):5809. https://doi.org/10.1038/ ncomms6809.

45. Lu W, Tinsley HN, Keeton A, Qu Z, Piazza GA, Li Y. Suppression of Wnt/betacatenin signaling inhibits prostate cancer cell proliferation. Eur J Pharmacol. 2009;602(1):8-14. https://doi.org/10.1016/j.ejphar.2008.10.053.

46. Kim WK, Kwon Y, Jang M, Park M, Kim J, Cho S, et al. $\beta$-Catenin activation down-regulates cell-cell junction-related genes and induces epithelial-tomesenchymal transition in colorectal cancers. Sci Rep. 2019;9(1):18440. https://doi.org/10.1038/s41598-019-54890-9.

47. Yochum GS, Sherrick CM, Macpartlin M, Goodman RH. A beta-catenin/ TCF-coordinated chromatin loop at MYC integrates 5' and 3' Wnt responsive enhancers. PNAS. 2010;107(1):145-50. https://doi.org/10.1073/ pnas.0912294107.

48. Yochum GS. Multiple Wnt/ß-catenin responsive enhancers align with the MYC promoter through long-range chromatin loops. PLoS One. 2011;6(4): e18966. https://doi.org/10.1371/journal.pone.0018966.

49. Bisso A, Filipuzzi M, Gamarra Figueroa GP, Brumana G, Biagioni F, Doni M, et al. Cooperation between MYC and $\beta$-catenin in liver tumorigenesis requires yap/Taz. Hepatology. 2020;72(4):1430-43. https://doi.org/10.1002/ hep.31120.

50. Yang J, Mani SA, Donaher JL, Ramaswamy S, Itzykson RA, Come C, et al. Twist, a master regulator of morphogenesis, plays an essential role in tumor metastasis. Cell. 2004;117(7):927-39. https://doi.org/10.101 6/j.cell.2004.06.006.

51. Wang F, Zhang G, Xing T, Lu Z, Li J, Peng C, et al. Renalase contributes to the renal protection of delayed ischaemic preconditioning via the regulation of hypoxia-inducible factor-1a. J Cell Mol Med. 2015;19(6):1400-9. https://doi.org/10.1111/jcmm.12527.

52. Zhu $Y$, Tan J, Xie H, Wang J, Meng $X$, Wang R. HIF-1 regulates EMT via the snail and $\beta$-catenin pathways in paraquat poisoning-induced early pulmonary fibrosis. J Cell Mol Med. 2016;20(4):688-97. https://doi.org/1 $0.1111 / \mathrm{jcmm} .12769$. 
53. Konisti S, Kiriakidis S, Paleolog EM. Hypoxia--a key regulator of angiogenesis and inflammation in rheumatoid arthritis. Nat Rev Rheumatol. 2012;8(3):15362. https://doi.org/10.1038/nrrheum.2011.205.

54. Agarwal SK, Guru SC, Heppner C, Erdos MR, Collins RM, Park SY, et al. Menin interacts with the AP1 transcription factor JunD and represses JunDactivated transcription. Cell. 1999;96(1):143-52. https://doi.org/10.1016/ S0092-8674(00)80967-8.

55. Wasylishen AR, Sun C, Chau GP, Qi Y, Su X, Kim MP, et al. Men1 maintains exocrine pancreas homeostasis in response to inflammation and oncogenic stress. PNAS. 2020;117(12):6622-9. https://doi.org/10.1073/pnas.1920017117.

56. de la Taille A, Rubin MA, Chen MW, Vacherot F, de Medina SG, Burchardt M, et al. Beta-catenin-related anomalies in apoptosis-resistant and hormonerefractory prostate cancer cells. Clin Cancer Res. 2003;9(5):1801-7.

57. Valkenburg KC, Graveel CR, Zylstra-Diegel CR, Zhong Z, Williams BO. Wnt/Bcatenin signaling in Normal and Cancer stem cells. Cancers (Basel). 2011; 3(2):2050-79. https://doi.org/10.3390/cancers3022050.

58. Wan X, Liu J, Lu JF, Tzelepi V, Yang J, Starbuck MW, et al. Activation of $\beta$-catenin signaling in androgen receptor-negative prostate cancer cells. Clin Cancer Res. 2012;18(3):726-36. https://doi.org/10.1158/1078-0432. CCR-11-2521

59. Bertolino P, Tong WM, Herrera PL, Casse H, Zhang CX, Wang ZQ. Pancreatic beta-cell-specific ablation of the multiple endocrine neoplasia type 1 (MEN1) gene causes full penetrance of insulinoma development in mice. Cancer Res. 2003:63(16):4836-41.

60. Seigne C, Auret M, Treilleux I, Bonnavion R, Assade F, Carreira C, et al. High incidence of mammary intraepithelial neoplasia development in Men1disrupted murine mammary glands. J Pathol. 2013;229(4):546-58. https://doi. org/10.1002/path.4146.

61. Shin S, Im HJ, Kwon YJ, Ye DJ, Baek HS, Kim D, et al. Human steroid sulfatase induces Wnt/ $\beta$-catenin signaling and epithelial-mesenchymal transition by upregulating Twist1 and HIF-1a in human prostate and cervical cancer cells. Oncotarget. 2017;8(37):61604-17. https://doi.org/10.1 8632/oncotarget.18645

62. Majumder PK, Febbo PG, Bikoff R, Berger R, Xue Q, McMahon LM, et al. mTOR inhibition reverses Akt-dependent prostate intraepithelial neoplasia through regulation of apoptotic and HIF-1-dependent pathways. Nat Med. 2004:10(6):594-601. https://doi.org/10.1038/nm1052.

63. Wei SC, Fattet L, Tsai JH, Guo Y, Pai VH, Majeski HE, et al. Matrix stiffness drives epithelial-mesenchymal transition and tumour metastasis through a TWIST1-G3BP2 mechanotransduction pathway. Nat Cell Biol. 2015;17(5):67888. https://doi.org/10.1038/ncb3157.

64. Xiang L, Gilkes DM, Hu H, Takano N, Luo W, Lu H, et al. Hypoxia-inducible factor 1 mediates TAZ expression and nuclear localization to induce the breast cancer stem cell phenotype. Oncotarget. 2014;5(24):12509-27. https://doi.org/10.18632/oncotarget.2997.

65. Yu S, Li Q, Yu Y, Cui Y, Li W, Liu T, et al. Activated HIF1a of tumor cells promotes chemoresistance development via recruiting GDF15-producing tumor-associated macrophages in gastric cancer. Cancer Immunol Immunother. 2020;69(10):1973-87. https://doi.org/10.1007/s00262-020-02 598-5.

66. Zhang $Q$, Yin $Y$, Zhao $H$, Shi Y, Zhang W, Yang Z, et al. P4HA1 regulates human colorectal cancer cells through HIF1a-mediated Wnt signaling. Oncol Lett. 2021;21(2):145. https://doi.org/10.3892/ol.2020.12406.

67. Qin J, Liu Y, Lu Y, Liu M, Li M, Li J, et al. Hypoxia-inducible factor 1 alpha promotes cancer stem cells-like properties in human ovarian cancer cells by upregulating SIRT1 expression. Sci Rep. 2017;7(1):10592. https://doi.org/10.1 038/s41598-017-09244-8.

\section{Publisher's Note}

Springer Nature remains neutral with regard to jurisdictional claims in published maps and institutional affiliations.

Ready to submit your research? Choose BMC and benefit from:

- fast, convenient online submission

- thorough peer review by experienced researchers in your field

- rapid publication on acceptance

- support for research data, including large and complex data types

- gold Open Access which fosters wider collaboration and increased citations

- maximum visibility for your research: over $100 \mathrm{M}$ website views per year

At BMC, research is always in progress.

Learn more biomedcentral.com/submissions 